\title{
THE HOME BIAS IN SOVEREIGN RATINGS
}

\author{
Andreas Fuchs \\ Heidelberg University, \\ Alfred-Weber-Institute for Economics \\ and Research Center for Distributional \\ Conflict and Globalization
}

\author{
Kai Gehring \\ University of Zurich \\ and University of Goettingen
}

\begin{abstract}
Using data on 143 sovereigns provided by nine agencies based in six countries, we estimate the determinants of sovereign ratings to test whether agencies assign higher ratings to their respective home countries, as well as to economically, geopolitically, and culturally aligned countries. Our regression results show that the respective home country, culturally more similar countries, and countries to which home-country banks have a larger risk exposure receive higher ratings than justified by their economic and political fundamentals. Cultural proximity, as measured by linguistic similarity, is shown to be the main transmission channel that explains the advantage of the home country. Further empirical tests that control for the existence of foreign offices and rated countries' levels of information transparency suggest that a more optimistic perception of risks rather than informational advantages drives this cultural home bias. (JEL: G24, F34, H63, F65, G15)
\end{abstract}

"The assessments by Standard \& Poor's appear dictated more by newspaper articles than reality and appear to be tainted by political considerations." (Italy's Prime Minister Silvio Berlusconi after his country was downgraded to "A" in September 2011)

The editor in charge of this paper was Nicola Gennaioli.

Acknowledgments: We are grateful for comments made by Christian Bjørnskov, Franscesco Caselli, Christian Conrad, Till Cordes, Jonas Dovern, Axel Dreher, Peter Egger, Pedro Forquesato, Roland Hodler, T. Florian Kauffeldt, Stephan Klasen, Lukas Menkhoff, Pablo Pinto, Constantin Schön, Rachel Wellhausen, Kevin L. Young, three anonymous reviewers, and the editor of this journal. We further thank seminar participants at Heidelberg University (2012-2013), ETH Zurich (09/2013), University of Hanover (12/2013), HSU Hamburg (03/2014), and Harvard University (10/2014), as well as conference participants at the CEA Conference in Montreal (06/2013), the APSA Meeting in Chicago (08/2013), the EPCS Meeting in Cambridge (04/2014), the SMYE Meeting in Vienna (04/2014), the IEA World Congress in Jordan (06/2014), the BBQ Workshop in Heidelberg (06/2014), the CMES Meeting in Xiamen (06/2014), and the VfS Conference in Hamburg (09/2014) for helpful comments on earlier versions of this paper. Andreas is grateful for support from the Niehaus Center of Globalization and Governance at Princeton University, where part of this research was carried out. Excellent research assistance was provided by Lutz Brückner, Elisabeth Dorfmeister, Jamie Parsons, Sven Kunze, Samuel Siewers, and Helge Zille.

E-mail: mail@ andreas-fuchs.net (Fuchs); mail@kai-gehring.net (Gehring) 
"If I ever dictated anything, it must have been what $S \& P$ had to say about domestic Italian economic policy." (Italy's Prime Minister Mario Monti after his country was downgraded to "BBB" in January 2012)

\section{Introduction}

The accuracy of sovereign ratings is important as rating outcomes can affect the borrowing costs of states (e.g., Afonso et al. 2012), can set de facto ceilings to corporate ratings (e.g., Durbin and Ng 2005; Borensztein et al. 2013) and-as argued by some-might even trigger or aggravate financial crises (e.g., Ferri et al. 1999; Kaminsky and Schmukler 2002; Gärtner et al. 2011). Ideally, competition and concerns over reputation should incentivize agencies to publish accurate and unbiased ratings. However, some scholars and policymakers around the world accuse credit rating agencies of having unreliable practices, intentionally publishing ratings at unfortunate times and making calculated misjudgments. For example, Germany's finance minister Wolfgang Schäuble speaks of “abusive behavio[u]r”, Turkey’s president Recep Tayyip Erdoğan makes claims of "unfair" decisions, and José Manuel Barroso, then president of the European Commission, directly accuses the agencies of a "bias [...] when it comes to the evaluation of specific issues of Europe". ${ }^{1}$ A common argument behind these accusations of biased ratings is that ratings are influenced by factors other than the economic and political fundamentals of rated countries-whether intentionally, through the demands of invested parties, or unintentionally, through factors that influence the supply of ratings.

Our study focuses on the concerns centered on the potential role of the credit rating agency's "home country". ${ }^{2}$ We define "home country" as the country where the agency's headquarters is located. Accordingly, we refer to a "home bias" in sovereign ratings if a rating agency assigns a higher rating to its home country or to countries with close economic, political, and cultural ties to it, holding everything else constant. As such, a home bias is a deviation of the actual rating level from what would be predicted based on the sovereign's economic and political fundamentals.

Our line of reasoning builds on and adds to the literature on home biases in investment decisions, bank lending behavior, and trade (e.g., French and Poterba 1991; McCallum 1995; Tesar and Werner 1995; Wolf 2000; Flandreau 2006; Presbitero et al.

1. See reports by Express Tribune (http://tribune.com.pk/story/211912/breaking-the-oligopoly-ratingsagencies-under-attack-amid-debt-crisis/; accessed 13 June 2013), Today's Zaman (https://web.archive.org/ web/20120530143333/http://www.todayszaman.com/news-280044-.html; accessed 6 August 2016), and BBC News (http://www.bbc.co.uk/news/business-14043293; accessed 12 September 2013).

2. The then E.U. Justice Commissioner Viviane Reding, for example, voiced in 2014 that "whenever the budgetary situation in the US worsens, certain risk rating agencies turn their guns on Europe" (see http://en.mercopress.com/2012/07/26/ec-criticizes-us-risk-rating-agencies-handling-of-the-euro-zonecrisis; accessed 23 May 2014). Sean Egan, president of the small U.S.-based agency Egan-Jones, criticizes the "current system" as being "New York-centered" and wants to "bring the perspective of China and Russia to the table" with the foundation of a joint venture of agencies from China, Russia, and the United States (see http://rt.com/business/chinese-ratings-agency-alternative-us-004/, accessed 13 June 2013). 
2014). Several studies have directly or indirectly addressed the question of a home bias in corporate and municipal bond ratings (e.g., Ammer and Packer 2000; Shin and Moore 2003; Güttler and Wahrenburg 2007; Cornaggia et al. 2015). Although sovereigns' incentives to default differ from those of other debtors (e.g., Grossman and Van Huyck 1988; Tomz and Wright 2007; Panizza et al. 2009) and despite the important role sovereign ratings play in determining many countries' access to capital markets, there has been no systematic study of home biases in sovereign ratings. Even small biases can have large consequences for refinancing costs, especially if they push countries below or above certain thresholds (e.g., Rigobon 2002; Jaramillo and Tejada 2011).

A simple comparison of the sovereign ratings issued by the China-based and Chinese-owned agency Dagong and the big three US-based agencies (Fitch, Moody's and Standard \& Poor's) illustrates why one might perceive ratings as influenced by the agency's home country. Compared to the "Big Three", Dagong consistently assigns higher ratings to Chinese Hong Kong and Macao as well as to the group of BRIC countries, including China itself, whereas assigning lower ratings to many Western economies. ${ }^{3}$ Similarly, Gaillard (2012, p. 89) observes that Japanese agencies seem to be "more indulgent, particularly when rating Asian governments, in ways that do not reflect [...] official methodologies". The existing literature does not explain these stark differences between agencies. Up until now, scholarship has largely explained sovereign ratings by the economic and political characteristics of rated countries (e.g., Cantor and Packer 1996; Afonso 2003; Archer et al. 2007). However, systematic research on the role of the rating agencies' home country in rating decisions is still lacking-despite the increased attention economists, policy makers and regulators have devoted to the topic since the Global Financial Crisis. Our article fills this gap in the literature.

Why would a rating agency's home country matter for sovereign ratings? We discuss the demand and supply factors that could influence the different stages of the rating decision process and thereby the final rating outcome. Specifically, the rating process might be subject to political pressure and "lobbying" activities of private actors. Moreover, cultural distance between the home country of the agency and the rated country could affect ratings. As we explain below in greater detail, the economic situation of a country that is culturally closer to the home country of the rating agency can appear more positive to its analysts than that of a culturally more distant but otherwise comparable country. Thus, our work also contributes to the literature on familiarity and cultural biases in economic decision making (e.g., Grinblatt and Keloharju 2001; Huberman 2001; Guiso et al. 2006, 2009; Giannetti and Yafeh 2012).

This article tests whether, conditional on the economic and political fundamentals of rated countries, credit rating agencies assign higher ratings to their home country, as well as to countries that are geopolitically and economically aligned with,

3. Note that Dagong and S\&P both provide an "AAA" rating to Hong Kong. Comparison as of June 28, 2013. Data from Bloomberg and Fitch. 
or culturally similar to it. For this purpose, we use monthly dyadic panel data on ratings of up to 143 sovereigns that have been issued by nine rating agencies based in six countries between January 1990 and June 2013. We first find that the average agency assigns a rating to its home country that, on a 21-point scale, is almost one rating category higher than can be justified by how it assesses other sovereigns. Second, there is no robust empirical support that geopolitical ties between home and sovereign play a significant role in rating outcomes, but agencies provide relatively higher ratings to countries to which home-country banks have a larger risk exposure. Third, cultural proximity is related to higher ratings: the larger the linguistic differences between home and sovereign, that is, the more unfamiliar their respective languages are, the lower the assigned rating. These biases are economically significant and can affect countries' access to international financial markets, their borrowing costs, and their stock markets (e.g., Kaminsky and Schmukler 2002; Afonso et al. 2012).

Our results are remarkably robust to the choice of the time period under analysis and the selection of control variables and estimation methods. We take several steps to come as close as possible to a causal interpretation of our results. First, our three main findings remain robust to augmenting the specification with additional fixed effects. This shows that these results are not driven by factors that are time-invariant in our sample such as the advantage that the United States enjoys with the US dollar being the world's reserve currency. Second, we run agency-specific regressions that allow for differential weights and assessments across agencies, the results of which confirm our main conclusions. Third, we show that our findings are not caused by selection into the sample of rated countries. Fourth, using quantile regressions, we also demonstrate that the effect of cultural distance is significantly negative not only at important thresholds, such as the investment-grade status, but also across all quintiles of the rating distribution.

The main channel that drives the differential treatment of the home country itself is cultural proximity. To ascertain why culture matters, we explore in greater detail whether information asymmetries or differences in risk perception contribute to cultural proximity's effect. Estimations that control for the existence of foreign offices and the countries' level of information transparency provide no indication that the cultural home bias is driven by informational advantages. Instead, we provide evidence suggesting that cultural proximity is associated with a more optimistic perception of risks related to higher bilateral trust.

The article proceeds as follows. In Section 2, we introduce the credit rating agencies and compare their key characteristics. Section 3 discusses demand and supply factors that could lead to a home bias in sovereign ratings. In Section 4, we introduce the data and econometric approach. Section 5 puts our hypotheses to an empirical test and presents our results. Finally, Section 6 summarizes, concludes, and outlines policy implications. 


\section{The Agencies}

Credit rating agencies are private companies that assess the creditworthiness of issuers of all types of bonds. Of the approximately 150 agencies worldwide, most are only active in a narrow national or regional market and focus solely on corporate ratings (White 2010; De Haan and Amtenbrink 2011). Only a small number of agencies issue sovereign ratings, eight of which provide sovereign ratings on Bloomberg: Capital Intelligence (CI), Dagong Global, Dominion Bond Rating Services (DBRS), Fitch Ratings, Japan Credit Rating Agency (JCR), Moody's Investors Service, Rating and Investment Information (R\&I), and Standard \& Poor's (S\&P). Feri EuroRating Services assigns ratings to 56 countries (and kindly provided their data to us). Our study covers these nine agencies based in six countries. ${ }^{4}$

Sovereign ratings, often used synonymously with the terms "sovereign credit ratings" or "sovereign debt ratings", are assessments of a country's creditworthiness. CI, for example, defines sovereign ratings as an indicator of "the ability and willingness of sovereign governments to repay existing and future commercial debt obligations on time and in full". 5 The rating scales are similar across agencies and follow letter designations, with "AAA" typically designating the highest category (see Online Appendix A1). As of June 2013, Switzerland, Finland, Liechtenstein, Luxembourg, and Norway are the only sovereigns that receive the top rating from all of the agencies that assign a rating to them. Ratings of "BB+" or lower are usually considered to be of "junk status", that is, to have a high expectation of default.

Table 1 provides an overview of the nine agencies covered in our study. The corporate history of S\&P dates back to the 19th century, but most smaller agencies started rating sovereigns in the late 1990s when a larger number of countries began to issue sovereign bonds. Still, the three large US-based agencies are the dominant players in the global rating market with several thousand employees each (White 2010). These so-called "Big Three" possess between 24 and 34 offices outside their home country. The other six agencies are smaller, but the interest in these companies is increasing, partly because investors from emerging markets play an increasingly important role in financial markets. For example, downgrades by Dagong receive significant media attention worldwide. ${ }^{6}$ Moreover, all of the agencies are officially

4. We thus do not cover very small agencies. The US-based Egan-Jones Ratings Company, for example, provides ratings for 19 sovereigns only (http://www.egan-jones.com/; accessed 24 September 2013). Another example is the Ukrainian rating agency Credit-Rating that only issues sovereign ratings for member countries of the Commonwealth of Independent States (see http://www.credit-rating.ua; accessed 17 September 2013).

5. See http://www.ciratings.com/page/rating-methodologies/sovereign-ratings (accessed 18 October 2013). Sovereign ratings are not to be confounded with "country risk ratings", which take a broader stance.

6. See, for example, articles on the websites of The Economist (http://www.economist.com/blogs/ buttonwood/2011/08/debt-ceiling-crisis-1; accessed 13 November 2013), and the Wall Street Journal (http://blogs.wsj.com/moneybeat/2013/10/17/chinas-dagong-takes-aim-at-u-s/?KEYWORDS=dagong; accessed 13 November 2013). 


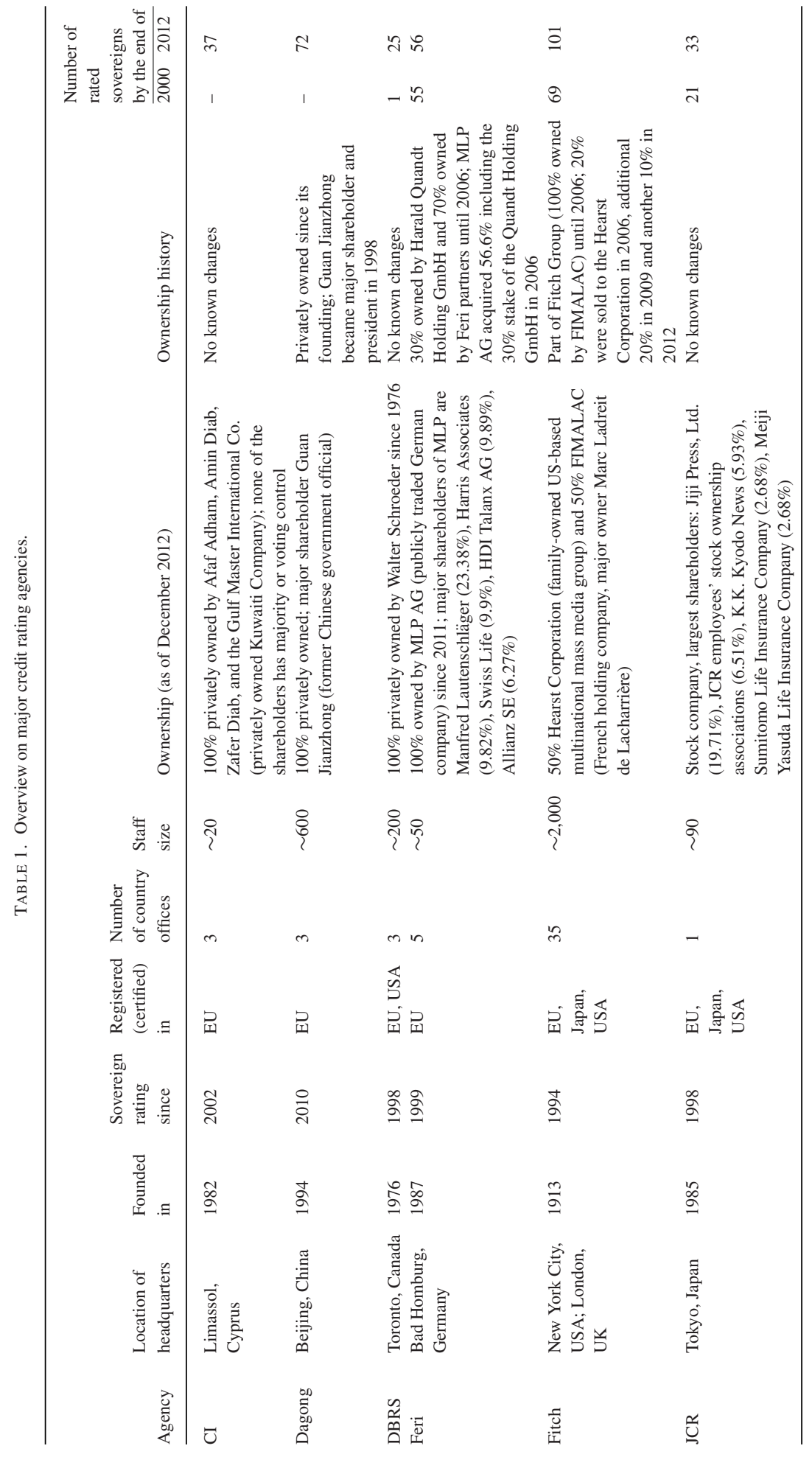




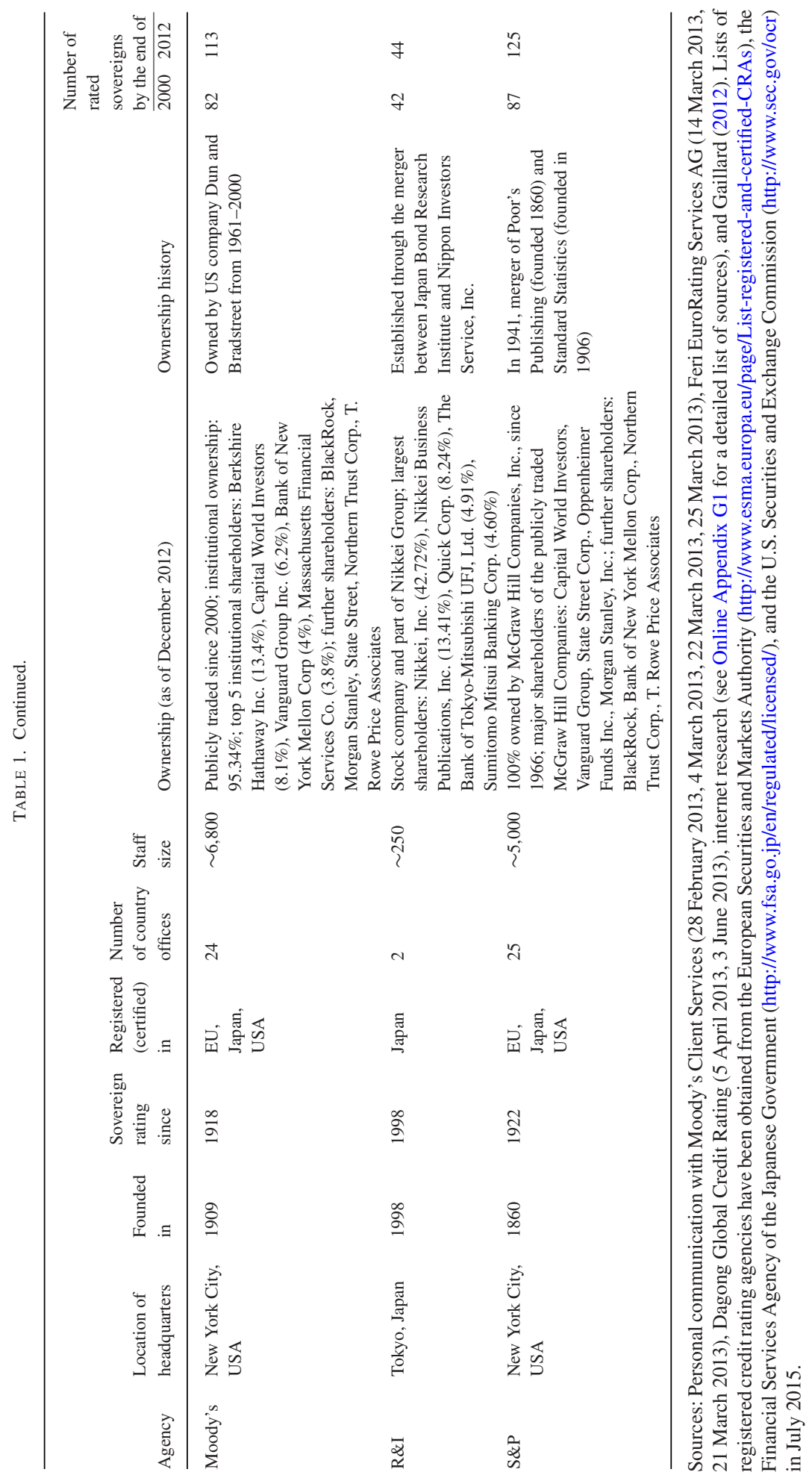


recognized, registered, or certified in the European Union, Japan, and/or the United States. Depending on the regulation in the specific market, one of these statuses is required so that banks can use these agencies' ratings for the computation of their capital requirements.

Banks and other financial institutions are among the most important shareholders of most credit rating agencies. For example, the Vanguard Group, the Bank of New York Mellon Corp., and BlackRock Inc. are shareholders of both Moody's and S\&P. The vertical and horizontal cross holdings have led to concerns about the influence of banks as shareholders if they are also invested in rated securities. ${ }^{7}$ Dagong and DBRS, in turn, are owned by private individuals. In two cases, the home country as determined by the agency's headquarters is not identical to the home country as defined by the citizenship of the agency's major shareholders. The US-based agency Fitch was 100\% owned by the French holding company FIMALAC until 2006 (which still holds 50\% of the shares), and Cyprus-based CI is owned by a privately owned Kuwait-based company and three individuals.

There are huge discrepancies with respect to the country coverage of the rating agencies. While S\&P has the widest coverage with 125 countries (and territories), DBRS covers the least (25). The smaller agencies typically focus on (culturally and geographically) closer countries, supposedly in line with their competitive advantage. DBRS, for example, successively expanded first to the Americas and then to other world regions (see maps in Online Appendix A2). Agencies also differ with respect to their business model: whereas CI and Feri only assign unsolicited ratings, the remaining agencies provide both unsolicited and solicited ratings (Online Appendix A3). According to S\&P, unsolicited ratings are provided when the agency "believe[s] there is significant market interest in them and there is also sufficient public information of reliable quality to support our analysis and ongoing surveillance" (S\&P 2012, p. 6).

Finally, and most importantly in the context of this study, there are also striking differences with respect to the ratings assigned. The maps in Figure 1 show that Moody's rates the United States with the top-notch "AAA", whereas Chinese Dagong only assigns an "A", that is, five rating categories lower (see Online Appendix A4 for maps for the remaining agencies). Table 2 compares the (average) rating assigned to each home country by its respective home agencies to the average rating received from all other agencies. As of June 2013, seven out of eight home countries receive a higher rating from their home agencies. We now turn to potential theoretical explanations for such differences.

7. The European Commission speaks of "shareholders that sometimes overlap" and "risk of conflicts of interest that could affect the quality of rating". Its new rules specifically "require CRAs [credit rating agencies] to disclose publicly if a shareholder with $5 \%$ or more of the capital or voting rights holds $5 \%$ or more of a rated entity" and "prohibit ownership of $5 \%$ or more of the capital or the voting rights in more than one CRA" (see European Commission MEMO/13/13 available at http://europa.eu/rapid/press-release_MEMO-13-13_en.htm, accessed 11 December 2013). 


\section{(a) Dagong (China)}

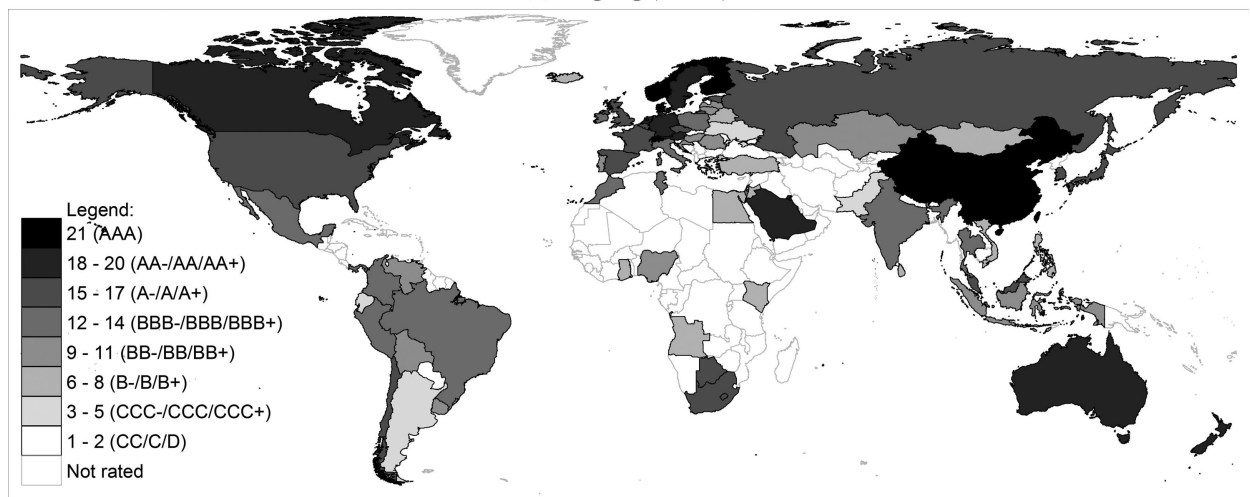

(b) Moody's (USA)

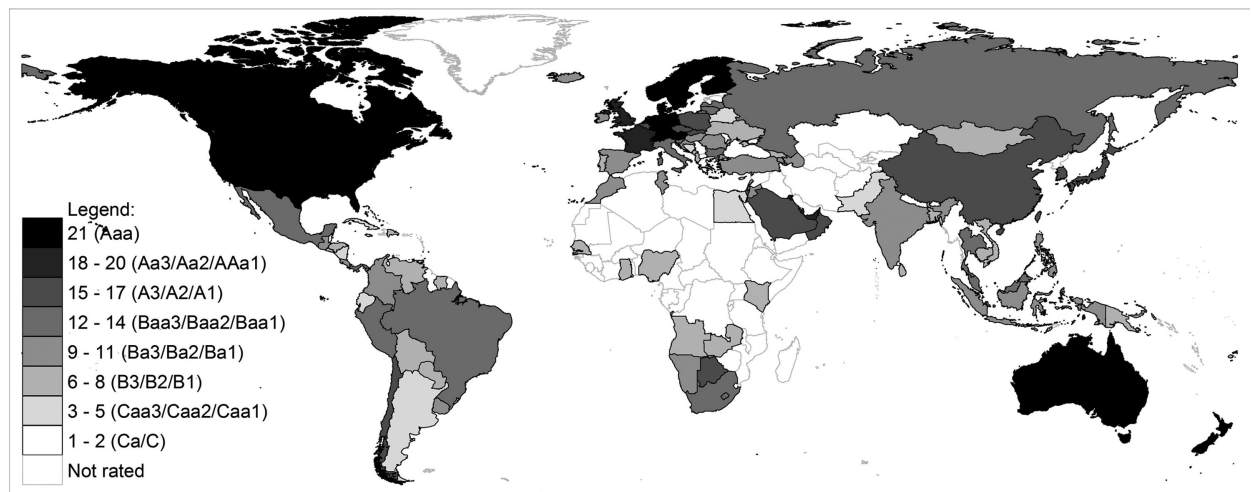

FIGURE 1. Sovereign ratings by agency and country (as of 28 June 2013).

TABLE 2. Sovereign ratings of home countries (as of June 2013).

\begin{tabular}{|c|c|c|c|c|c|c|c|c|}
\hline & Canada & China & Cyprus & Germany & France & Japan & Kuwait & United States \\
\hline Home agencies & AAA (21) & AAA (21) & B (7) & AAA (21) & AAA (21) & AAA (20.5) & AA- (18) & AAA (20.7) \\
\hline Other agencies & AAA (20.7) & $\mathrm{AA}-(18)$ & CCC (4.4) & AAA (20.9) & $\mathrm{AA}+(19.9)$ & $\mathrm{A}+(17.4)$ & AA (19) & $\mathrm{AA}+(19.8)$ \\
\hline
\end{tabular}

Note: Each cell displays the three-letter rating (and its numerical equivalent, see Appendix A1). In cases where more than one (home or other) agency assigns a rating to a particular country, the table displays the respective average.

\section{Why the Home Country Could Matter}

In their seminal paper, Cantor and Packer (1996) investigate the economic determinants of rating assignments by the US agencies Moody's and S\&P. They identify a set of key factors, corroborated by Afonso (2003), which contains GDP per capita, GDP growth, past default experience, the inflation rate, external debt, and an industrialized-country 
dummy variable. ${ }^{8}$ Other recent studies focus on political determinants of sovereign ratings and examine a potential "democratic advantage" (Archer et al. 2007; Beaulieu et al. 2012; Biglaiser and Staats 2012) and political business cycles (Block and Vaaler 2004; Vaaler et al. 2006), among others. Overall, political factors have been shown to play an important, though smaller, role compared to economic fundamentals (Haque et al. 1998; Archer et al. 2007).

The findings of the previous literature have two important caveats. First, most of the literature analyzes only sovereign ratings issued by the big three U.S.-based agencies. ${ }^{9}$ To the best of our knowledge, no empirical study has looked at a broad set of rating agencies to analyze the determinants of sovereign ratings. Second, the previous literature does not offer explanations for the marked differences in ratings between agencies. Scholars so far explain sovereign ratings $r$ issued by a rating agency $a$ based in home country $j$ only with the characteristics of the rated country $i$ at time $t$ :

$$
r_{a, j, i, t}=f\left(e_{i, t}, p_{i, t}\right),
$$

where $e$ stands for the economic fundamentals and $p$ for the political fundamentals of the rated country. This approach ignores the potential role played by the location of the agency's headquarters and the nationality of its main shareholders.

Although all agencies follow similar procedures to determine their ratings, ${ }^{10}$ the agencies differ in a number of ways including their ownership structure, regulatory environment, and the (cultural) background of their staff. A home bias could thus be related to the demand and supply side of the rating production process. On the demand side, agencies have incentives to draft ratings in a way that caters for their respective home country's economic and geopolitical interests. Governments as well as the agencies' major shareholders and clients might, for instance, put pressure on rating agencies to issue higher ratings to the home country or countries aligned with it. On the supply side, agencies have to gather and process primary and secondary information for their assessments. In such an incomplete information framework, agencies could provide higher ratings to culturally more similar countries as they have an advantage in accessing and processing information. They could also interpret the available information in a more favorable way. We thus hypothesize that homesovereign pair-specific variables $x_{j, i, t}$ explain sovereign ratings in addition to the economic and political fundamentals specific to country $i$. Extending equation (1)

8. Hill et al. (2010) identify a similar set of common determinants of sovereign ratings: GDP per capita, GDP growth and its square, past default experience, country risk rating, and risk premiums.

9. Exceptions include Alsakka and ap Gwilym (2010, 2012), who analyze leads and lags as well as split ratings between Japanese and US agencies in emerging markets, and Bartels (2014), who compares ratings by Germany-based Feri to its US competitors.

10. The usual process can be grouped into four phases: Rating Initiation, Due Diligence, Rating Assignment, and Rating Publication. Details can be found in Online Appendix A5. Differences in the rating process between the nine agencies under analysis are summarized in Online Appendix A6. 
from above, we obtain

$$
r_{a, j, i, t}=f\left(x_{j, i, t}, e_{i, t}, p_{i, t}\right)
$$

\subsection{Demand-Side Explanations}

Credit rating agencies are closely intertwined with the domestic economy and derive a large share of their income from their respective home market. Several actors with leverage over rating agencies may explicitly or implicitly demand more favorable ratings for their home country and countries aligned with it. First of all, governments have incentives to lobby for higher ratings. Sovereign ratings determine the extent to which countries can access international capital markets, particularly in the case of emerging and developing economies (e.g., Cantor and Packer 1996; Larraín et al. 1997). Even for industrialized economies with well-established market access, rating downgrades influence sovereigns' borrowing costs (Afonso et al. 2012). One important reason is that certain institutional investors are bound by regulations or their own charters to only invest in assets above certain rating thresholds ("hardwiring of ratings"). For example, the US Securities and Exchange Commission (SEC) restricts money market funds to only purchase securities rated by any two Nationally Recognized Statistical Rating Organizations (NRSRO) in one of the two highest rating categories. Moreover, governments care about sovereign ratings as these assessments are interpreted as a signal of the performance of the political leadership. For example, the downgrades of France in 2012 and 2013 were perceived as constituting "politically a heavy blow for the head of state", President François Hollande. ${ }^{11}$

Governments do not only have incentives to influence their own ratings but also those of countries with which they have strong ties, for example, to avoid spillovers affecting the domestic sovereign debt market (see Böninghausen and Zabel 2015). Moreover, downgrades and potentially resulting instabilities of economically close countries may harm the home country's export interests and endanger the investments of domestic actors. Home-country governments also have an interest in avoiding a potentially destabilizing downgrade of geopolitically aligned countries, that is, countries with which they collaborate in international fora or that are of military importance. An important reason is that countries with affordable credit access have a lower probability of experiencing civil conflict (DiGiuseppe et al. 2012). Taken together, governments have numerous incentives to demand that their own and aligned countries' rating remains high since downgrades come with economic and political costs. Based on the same reasoning, downgrades of nonaligned countries could appear desirable.

11. See an article by France's leading financial newspaper, Les Échos, available at http://www.lesechos.fr/ economie-politique/politique/actu/0203115388893-degradation-de-la-note-de-la-france-un-nouveau-coup -dur-pour-1-executif-627380.php (accessed 30 November 2011, own translation of the quote). This reasoning is related to research on the political costs of sovereign default (Borensztein and Panizza 2009). 
Although governments lack the power to directly influence assessments by the privately owned credit rating agencies, there is a questionable dependence of agencies on governments that provides the latter with some leverage. In the European Union and the United States, for example, only the ratings of officially recognized agencies can be used by companies to determine their capital requirements (White 2010; De Haan and Amtenbrink 2011). Dagong, for example, was denied recognition as a Nationally Recognized Statistical Rating Organization (NRSRO) in the United States in September 2010. The prospect of losing their recognition is an imminent threat to agencies. This is particularly the case for agencies' home markets, which are usually the major source of their income. ${ }^{12}$

Anecdotal evidence suggests that governments indeed try to use their influence to impact rating decisions. Two weeks after the US rating agency Egan-Jones downgraded the United States to "AA" in 2012, the US Securities and Exchange Commission (SEC) brought administrative action against the firm for alleged "material misstatements" during its application for regulatory approval in 2008. In this context, the owner of Egan-Jones, Sean Egan, stated that "[w]e are not going to be intimidated by anybody from issuing timely, accurate ratings." ${ }^{13}$ In a similar case, S\&P claimed that the US\$ 5 billion lawsuit brought against it by the US government was "a retaliation for its 2011 decision to strip the country of its AAA credit rating. ${ }^{14}$

In addition to governments, banks and other financial institutions, which are among the major shareholders of most rating agencies, might exploit their leverage to influence the agencies' decision-making. Shin and Moore (2003, p. 331) cite a report by the Japan Center for International Finance, according to which " $[\mathrm{t}]$ he composition of the shareholders of rating agencies may impair the impartiality of ratings." Shareholders could try to obtain a preferential treatment of countries where they are exposed to large risks, for example, where they have a large amount of outstanding loans. Gennaioli et al. (2014), for example, show the negative spillovers of a country's sovereign default on the domestic banking system as it destroys balance sheets of home-country banks, which are over-proportionally exposed to their governments' bonds. Along similar lines, home-country banks have more incentives to lobby against downgrades of foreign countries to which they have an over-proportional risk exposure since these would also affect their balance sheets in a particularly adverse way. Another reason why banks are negatively affected by sovereign downgrades is that they lower the de

12. For example, $57 \%$ of Moody's revenue in 2015 was generated in the United States (see press release at http://s21.q4cdn.com/431035000/files/doc_news/2016/1001206640.pdf; accessed 6 August 2016). Dagong is even more dependent on its home market, with more than $95 \%$ of its corporate ratings revenue coming from Chinese clients (e-mail correspondence with Dagong on 23 December 2015). As suggested by a reviewer, given the importance of the corporate sector, agencies could also use inflated ratings to attract business. Corporations in the home country might infer from the more favorable treatment of the home country that they could also obtain a higher rating than from a foreign agency.

13. See http://online.wsj.com/news/articles/SB10001424052702303513404577354023825841812 (accessed 18 November 2013).

14. See, for example, an article by Reuters available at http://www.reuters.com/article/2013/09/03/ us-mcgrawhill-sandp-lawsuit-idUSBRE98210L20130903 (accessed 15 December 2013). 
facto ceilings to corporate ratings (Durbin and $\mathrm{Ng} 2005$; Borensztein et al. 2013) and thus decrease the value of corporate investments.

Such explicit and implicit demands from governments and financial institutions could explain why agencies provide more favorable ratings to their home countries and economically and geopolitically closer countries. Demand-driven biases are more likely to occur during the later stages of the rating process. Although analysts use (more or less) clearly defined quantitative and qualitative indicators for the initial rating proposal ("sovereign indicative rating level"), the rating committee has enough influence to be able to cater for the interests of the agency's home-biased clients and government; it has the ability to deviate from the "objective" rating proposal at its own discretion. S\&P, for example, speaks of "exceptional adjustment factors" that can make the agency deviate from the analysts' risk assessments (S\&P 2012).

Finally, one could hypothesize that analysts at rating agencies may be influenced by considerations of how their ratings will affect the banking sector: analysts can easily transition to banking due to similar job requirements and considerations of hurting future employers may enter their calculations. In this context, Bar-Isaac and Shapiro (2011) model a "revolving door" that connects rating agencies and investment banks. Cornaggia et al. (2016) argue that analysts have incentives to take their career opportunities into account and assign higher ratings to corporations that they consider as being attractive future employers. Similarly, sovereign rating analysts could consider to rate countries higher in which home-country banks are strongly invested than would otherwise be justified.

\subsection{Supply-Side Explanations}

The existence of a home bias in financial decision-making is well established in the literature. Equity investment disproportionately flows into investors' home country (French and Poterba 1991) and within their home country into their home region (Coval and Moskowitz 1999). Moreover, firms favor more familiar overseas listing venues (Sarkissian and Schill 2004), and mutual funds are biased towards domestic stocks (Chan et al. 2005). Grinblatt and Keloharju (2001, p. 1072) argue that "familiarityrelated effects could be the major contributor to home bias" and relate the familiarity bias to culture. Their empirical analysis shows that cultural proximity influences stockholdings of both private and corporate investors. With respect to syndicated bank loans, Giannetti and Yafeh (2012) show that lenders treat borrowers from culturally more distant countries as less reliable: they receive smaller loans, pay higher interest rates and are more often required to provide a third-party guarantee. Given this evidence, it would not be surprising if culture also affects decision-making at rating agencies.

Culture can affect both the amount of collected information and the interpretation of the available information. Agencies operate in an incomplete information framework where they have to gather and process both hard and soft information. Hard information can be thought of as being more quantitative in nature, usually available on public domains and thus more objective and largely identical across all agencies. Soft 
information is more qualitative in nature, costly to collect and leaves more room for interpretation due to its subjectivity (Alsakka and ap Gwilym 2012). It is typically acquired through communication with the sovereign, for example, at meetings with representatives of the government or central bank. Agencies have to decide how much information they collect and cope with concerns regarding the reliability and accuracy of the acquired information. We discuss three lines of reasoning how cultural proximity can affect rating decisions. These are based on information asymmetries, differences in risk perceptions, and taste-based discrimination.

First, information asymmetries between agencies could lead to a home bias in sovereign ratings as agencies might possess more and better information of the home country and culturally closer countries (for similar arguments see Gehrig 1993; Brennan and Cao 1997; Kang and Stulz 1997). The most obvious reason is that information costs are higher for unfamiliar investments (see Chan et al. 2005). Giannetti and Yafeh (2012) argue that, facing a tradeoff between the benefits of acquiring additional information and reducing transaction costs, the higher costs of information gathering create an equilibrium outcome where less information is collected about culturally more distant borrowers. We know from the trade literature that transaction costs increase with cultural differences (e.g., Felbermayr and Toubal 2010). Linguistic dissimilarities in particular constitute barriers to direct communication and increase the difficulty of translations (e.g., Melitz 2008). Applying this logic to rating decisions, agencies should possess inferior information about culturally more distant countries. It is obvious that inferior information leads to less precise ratings but it is less clear whether it necessarily translates into lower ratings.

One could however argue that inferior information translates into lower ratings since predictions of the sovereign's liquidity to serve its debts are less precise and thus imply a higher probability of defaulting. Assume that a rating agency estimates the liquidity $L$ of two sovereigns $i$, with $E\left[L_{i}\right] \sim N\left(\mu, \sigma_{i}^{2}\right)$. Further assume that a sovereign enters a state of default if $L_{i}<z$. Thus, the probability of default is $P\left(L_{i}<z\right)=F\left(|z-\mu| / \sigma_{i}\right)$. Assume that the two sovereigns $A$ and $B$ possess identical country characteristics, that is, have the same expected value $\mu$, but sovereign $B$ is culturally more distant to the home country of the rating agency. As a result of higher transaction costs, the agency collects less information about the characteristics of sovereign $B$. This implies that its prediction of $L_{B}$ is less precise compared to that of $L_{A}$, that is, $\sigma_{B}^{2}>\sigma_{A}^{2}$. Thus, $F_{B}\left(|z-\mu| / \sigma_{B}\right)>F_{A}\left(|z-\mu| / \sigma_{A}\right)$ for all $z<\mu$, that is, the predicted default probability is higher for the culturally more distant sovereign, which could be reflected in a lower rating (see Gehrig 1993 for a similar argument).

The second explanation for the role of cultural proximity focuses on differences in the perception of the risks associated with political and economic fundamentals. Following the literature on an "optimism bias", a home bias does not require that the actors actually possess more or better information; it suffices that the actors perceive the acquired information more favorably. Early work by French and Poterba (1991) explains the home bias in portfolio holdings with domestic investors' more optimistic expectations about domestic stock returns compared to foreign stocks (see also Strong and Xu 2003). Similarly, Kilka and Weber (2000) find that that people hold more 
"optimistic" expectations about domestic investments as they feel more "competent" in evaluating investment possibilities at home. A possible explanation for these biased perceptions is put forward by Huberman (2001, p. 678) who claims that "[f]amiliarity is associated with a general sense of comfort with the known and discomfort witheven distaste for and fear of-the alien and distant." A stream of papers suggests that trust rooted in culture is a potential cause of differences in perceptions. Guiso et al. (2009), for instance, find that cultural distance translates into lower levels of bilateral trust, which then translates into less economic exchange between countries. Their analysis of bilateral investments concludes that "cultural effects are not limited to unsophisticated consumers, but are also present among sophisticated professionals" (p. 1098). Similarly, during the rating process, analysts could perceive the same information from a more familiar country as more reliable and its bonds as less risky. The role of familiarity should be particularly big — but not confined to-soft information, which is less quantifiable.

It seems plausible that higher bilateral trust in the people of a country is linked to a more positive assessment of the sovereign regarding its ability and particularly willingness to repay. This is in line with the argument of Cole and Kehoe (1998) that if a country appears trustworthy in one arena, the country is perceived as trustworthy in other arenas as well. Trust arguably plays a large role for sovereign ratings since the legal enforcement of sovereign debt repayments is (usually) impossible, which makes the sovereigns' incentives to repay differ from those of corporations. ${ }^{15}$ Since sovereigns can default for reasons other than liquidity concerns, it is not surprising that the negative link between economic performance and sovereign default is surprisingly weak (Tomz and Wright 2007). Independently of whether governments are maximizing welfare or reelection prospects, a government's decision to default is a function of the expected political and economic costs (see Borensztein and Panizza 2009; Panizza et al. 2009). The value of trust for sovereigns has already been spelt out by Grossman and van Huyck (1988, p. 1088), who note that "[t]he fact that the servicing of sovereign debts is not subject to external enforcement suggests that the decision by a sovereign not to repudiate its debts depends mainly on the sovereign's concern about its trustworthy reputation for validating lenders' servicing expectations." Hence, sovereigns can benefit from higher levels of bilateral trust. Since cultural proximity can lead to higher bilateral trust and a more optimistic perception of the risks associated with political and economic fundamentals, it seems plausible that culturally close countries obtain higher ratings, all else equal.

Finally, a third potential reason for the role of cultural distance is direct discrimination of certain ethnicities or races. Building on Becker (1961) and Stiglitz (1973), we define discrimination in our context as behavior that treats two sovereigns with the same economic and political characteristics differently based on ethnic or racial differences. Taste-based discrimination may negatively influence how

15. There is also a related literature which explains why private loans to foreign governments can exist under these circumstances. See Eaton and Gersovitz (1981) for a seminal paper and Panizza et al. (2009) for an overview. 
creditworthy borrowers are perceived to be (Giannetti and Yafeh 2012). Ravina (2008) provides empirical evidence that race affects credit conditions. Rating agency staff may exhibit similarly biased preconceptions toward sovereigns.

\section{Data}

\subsection{Dependent Variable: Sovereign Ratings}

Our dependent variable is a sovereign's long-term foreign-currency rating provided by one of nine rating agencies: CI, Dagong, DBRS, Feri, Fitch, JCR, Moody's, R\&I, and S\&P. We retrieve daily information on sovereign ratings by most agencies via Bloomberg (see Online Appendix B1 for details). The information on ratings published by Feri and Fitch is obtained directly from the agencies. We take the monthly average of the assigned ratings since the highest frequency for which the explanatory variables are available is also monthly. ${ }^{16}$ We obtain an unbalanced panel as each agency assigns ratings to different sets of countries over varying periods of time (Online Appendix B2). For our empirical analysis, all ratings have been translated to a 21-point scale. This means that we assign the highest value of 21 for an "AAA" rating. "C" and "D" in turn are translated into a value of one. The pair-wise correlation between sovereign ratings from the nine credit rating agencies under analysis ranges between 0.784 for CI and Feri and 0.987 for Fitch and S\&P (Online Appendix B3).

\subsection{Country-Pair-Specific Variables of Interest}

Based on our theoretical considerations, we use eight home-sovereign-pair-specific variables of interest to test for the existence of (and mechanisms behind) a home bias in sovereign ratings. As we argue, none of these variables should according to the agencies' rating methodologies influence sovereign ratings, controlling for the economic and political fundamentals of rated countries introduced in the next section. Starting with the most obvious test for a home bias, the same country dummy takes a value of one if the rated country is the home country of the rating agency. The home

16. While DBRS, Feri, and JCR follow a monthly updating interval, CI, R\&I and S\&P do not have such a fixed scheme (see again Online Appendix A6). Most of the literature uses yearly averages or year-end ratings rather than monthly averages. However, this results in a loss of information, most importantly since rating changes within a year are ignored. Moreover, sovereigns often receive their first rating in the course of a year and ratings can be withdrawn within a year. The usage of monthly data mitigates these problems compared to yearly averages or a simple extrapolation to the end of the year. There are even a couple of cases of repeated rating changes within a particular month. We observe such instances for $\mathrm{S} \& \mathrm{P}$ (28 times), Fitch (15), R\&I (8), Moody's (7), and JCR (1). 
country is defined as the country in which the headquarters of the agency are physically located. ${ }^{17}$

To test the demand channels, we analyze whether, controlling for economic and political fundamentals of rated countries, a rating agency assigns a better rating to countries in which the home country has stronger economic interests and to countries geopolitically aligned with the home country. We account for two variables that capture economic links between the home country of the rating agency and rated countries. First, export interests are measured by the rated country's share of the home country's total exports (data from UN Comtrade). While a sovereign's access to foreign currency should matter for its ability to pay back its debt (which is accounted for by a control variable current account balance), the sovereign's relative importance as an export market for the home country of the rating agency should, all else being equal, be unrelated to rating outcomes. Second, the variable bank exposure proxies for the importance of investments in the rated country for the home country's banks. The Bank for International Settlements provides data on bank exposure of all banks headquartered in most of our home countries. ${ }^{18}$ With values ranging between 0 and 100 , our measure of bank exposure is the risk exposure of home-country banks to a specific rated country as a share of the total risk exposure of home-country banks to all countries worldwide. To give an example, the January 2009 risk exposure of German banks to Ireland accounts for $5.5 \%$ of German bank's overall exposure to foreign countries.

We use two measures to test whether countries that are geopolitically aligned with the home country of the rating agency receive relatively higher ratings. First, we use bilateral voting alignment in the United Nations General Assembly as a proxy for geopolitical alignment between the home country of the rating agency and the rated country. This is defined as the share of votes in which the home country and the rated country exhibit the same voting behavior, that is, both voting yes, both voting no, or both abstaining (data from Strezhnev and Voeten 2012). As an illustrative example, consider the case of Malaysia, which is strongly aligned with China and receives on average a two-point higher rating from Dagong compared to the three big USbased agencies. Measures of UN voting alignment are widely used in the literature to measure bilateral affinity (e.g., Barro and Lee 2005; Dreher and Gassebner 2008; Qian and Yanagizawa 2009). For the US-based agencies in our sample, we also employ a country's share of the total US military aid as a second measure of geopolitical alignment. This variable, US military interests (aid), serves as a proxy for the strategic importance that the United States assigns to these countries.

17. We also run regressions where we code home countries according to the nationality of the major shareholder(s).

18. It contains detailed information on all foreign claims to the public sector, banks, and the non-bank private sector, as well as miscellaneous other claims. In addition, it covers potential exposures from derivatives contracts, guarantees and credit commitments. Unfortunately, no data are reported from Cyprus (CI) and China (Dagong). 
To test the supply channels, we analyze whether, controlling for economic and political fundamentals of rated countries, a rating agency assigns a better rating to countries that are culturally closer to the home country. We use three measures of cultural distance. The first variable common language is a dummy that takes a value of one if home and sovereign share the same official language (see also Chan et al. 2005; Guiso et al. 2009; data from Mayer and Zignago 2011). Moreover, we follow several studies that use more comprehensive measures of cultural distance (e.g., Guiso et al. 2009; Giannetti and Yafeh 2012). Specifically, we use two dimensions from Kolo's (2012) Distance-adjusted Ethno-Linguistic Fractionalization index (DELF). ${ }^{19}$ The second variable Cultural distance (language) measures linguistic differences based on language trees from the Ethnologue project, which classifies 6,656 distinct languages into families and branches due to their linguistic origin (Lewis 2009). As outlined before, larger cultural distance could be related to reduced information gathering and less optimistic risk perceptions. The third measure, cultural distance (ethnoracial) is derived from a biological taxonomy of species, based on genealogical relatedness. Kolo (2012) assigns six-letter codes, which are based on race, skin pigmentation, and ethnic origin and allow more differentiation between genetic groups than mere genetic distance (as in Spolaore and Wacziarg 2009, for example). Ethnoracial distance can be seen as a proxy for economic discrimination based on race or ethnicity; however, it might also be related to trust towards the rated country.

\subsection{Sovereign-Specific Control Variables}

We build on and combine the sets of explanatory variables employed in Cantor and Packer (1996), Archer et al. (2007), and Hill et al. (2010) to control for those country-specific economic and political factors that should "objectively" determine sovereigns' ability and willingness to repay their debt. ${ }^{20}$ To capture the sovereign's domestic economic performance, we employ the country's logged GDP per capita (in constant 2000 US dollars), GDP growth rate (including a squared term), inflation rate (based on consumer prices), and natural resources measured as total natural resource

19. The approach in Kolo (2012) builds on the Ethno-Linguistic Fractionalization index (ELF, Alesina et al. 2003). The cultural distance between two countries $A$ and $B$ is calculated as $D E L F=$ $\left(1-\sum_{k_{A}=1}^{K} \sum_{k_{B}=1}^{K} p_{k_{A}} p_{k_{B}} \hat{s}_{k_{A}, k_{B}}\right) \cdot 100$. The calculation weighs each distinct group $k$ within countries $A$ and $B$ by their relative group size $p_{k}$. The product of the weights is multiplied with a similarity parameter $\hat{s}_{k_{A}, k_{B}}$, which varies between zero and one and takes the value of one if individuals belong to the same cultural group. The resulting $D E L F$ value gives the expected similarity between two randomly drawn individuals.

20. The agencies do in practice augment these third-party variables with their own forward-looking forecasts, which cannot be controlled for. However, these constitute outcome variables rather than controls and should thus be considered as "bad controls" in the terminology of Angrist and Pischke (2008). In fact, the forward-looking assessments should mostly be affected by potential cognitive biases, as they require and leave more room for subjectivity. See also Online Appendix B4 for a summary of the factors that the nine agencies communicate in official documents. Comparing these factors with those employed in the literature, there is a large overlap but also an apparent lack of control for political risks in the previous literature. This is why we add further variables in this category (see also Gaillard 2012). 
rents as a percentage of GDP. To account for a sovereign's financial stability and fiscal performance, we control for a country's gross government debt-to-GDP ratio (government debt), its change over time (change in government debt), and two binary variables that account for reputational costs incurred from past defaults (default). ${ }^{21}$ We add the sum of the rated country's exports and imports (trade openness), current account balance, and debt owed to nonresidents (external debt) to account for a sovereign's external performance (all as a share of GDP).

We also control for eight measures of a sovereign's political and institutional performance: a sovereign's level of democracy (polity 2), a binary indicator of elections held during the last 12 months, the number of years the chief executive has been in office (years in office), a binary variable for executive ideology (left government), and indices for a country's rule of law, absence of internal conflict, absence of external conflict, and absence of military in politics. Finally, we also include logged population size and a binary variable whether a country is a member of the Eurozone.

These variables are drawn from the World Bank's World Development Indicators (WDI), the IMF (Abbas et al. 2010; Laeven and Valencia 2012), the Database of Political Institutions (Beck et al. 2001), the Polity IV Project (Marshall et al. 2013), and the International Country Risk Guide (ICRG). All time-varying control variables enter as lagged moving averages over one or three years. Online Appendices B5 and B6 provide precise definitions of all variables employed, their sources, details on the computation of the lags and descriptive statistics. Online Appendix B7 provides more details about the related literature and the theoretical motivation for including each variable.

\section{Econometric Analysis}

To test for the existence of (and the mechanisms behind) a home bias in sovereign ratings, we estimate the determinants of sovereign ratings $r_{a, j, i, t}$ using OLS:

$$
r_{a, j, i, t}=\beta x_{j, i, t}+e_{i, t}^{\prime} \gamma+p_{i, t}^{\prime} \delta+\alpha_{a, j}+\tau_{t}+\varepsilon_{a, j, i, t},
$$

where $x_{j, i, t}$ is a country-pair-specific variable of interest, $e_{i, t}$ and $p_{i, t}$ are vectors that contain sovereign-specific economic and political control variables, $\alpha_{a, j}$ and $\tau_{t}$ are agency- and period-fixed effects, respectively, and $\varepsilon_{a, j, i, t}$ is the error term. ${ }^{22}$ Error terms may be correlated at both the agency-time and sovereign level, which is why we

21. The first variable accounts for long-term reputational costs and takes a value of one if the sovereign has experienced a sovereign debt crisis or restructuring since 1970. In line with the findings of Borensztein and Panizza (2009), according to which such costs can be rather short-lived, the second variable takes a value of one if the sovereign has defaulted or restructured its debt in the last five years.

22. We use agency-fixed effects rather than home-country-fixed effects to account for differences in the average rating level that can exist between the agencies from one country. 
allow for two-way clustering on both dimensions. Data range from January 1990 to June 2013. ${ }^{23}$

Our identification strategy exploits three sources of variation in the dependent variable: (i) differences in the rating levels between rated countries, (ii) changes in ratings within rated countries, and (iii) differences in ratings between agencies for the same rated country at a specific point in time. Since ratings are rather sticky and exhibit little variation for some countries, we choose equation (3) as our baseline to be able to identify our coefficients based on all three sources of variation. To alleviate concerns about unobserved (time-invariant) characteristics of rated countries, we also show results for a specification that adds sovereign-fixed effects to equation (3):

$$
r_{a, j, i, t}=\beta x_{j, i}+e_{i, t}^{\prime} \gamma+p_{i, t}^{\prime} \delta+\alpha_{a, j}+\eta_{i}+\tau_{t}+\varepsilon_{a, j, i, t} .
$$

For the time-varying variables of interest $x_{j, i}$, we replace $\eta_{i}$ with stricter agencysovereign-pair-fixed effects $\eta_{a, j, i}$. Identification of $\beta$ in equation (4) rests on the variation caused by (ii) and (iii). The most restrictive specification is to use agencyand sovereign-time-fixed effects, which leads to identification of $\beta$ being based solely on variation caused by (iii). Using the previous notation, we obtain

$$
r_{a, j, i, t}=\beta x_{j, i}+e_{i, t}^{\prime} \gamma+p_{i, t}^{\prime} \delta+\alpha_{a, j}+\omega_{i, t}+\varepsilon_{a, j, i, t}
$$

For the time-varying variables of interest $x_{j, i, t}$, we replace $\alpha_{a, j}$ and $\omega_{i, t}$ by stricter agency-sovereign-pair-fixed effects $\omega_{a, j, i, t}$. Equation (5) minimizes the potential omitted variable bias, but identification is based only on variation across the nine agencies. Thus, for any $x_{j, i}, \beta$ is identified only by observations of countries rated by more than one agency at the same point in time where we observe a difference in ratings between these agencies. If our variables of interest pass this test as well, this provides strong evidence for a home bias in sovereign ratings. The coefficients and standard errors from equation (5) should be interpreted with caution however as this can be an overly restrictive test. If equation (5) leads to insignificant results, this can be due to a lack of variation as outlined above. Also, the estimated $\beta$ might not be representative for the entire sample in case of heterogeneous effects. For these reasons, we take equation (3) as a baseline specification and show the results based on equations (4) and (5) for comparison.

In addition to our regression results for the full sample, we also show results for a sample restricted to the time after the onset of the Global Financial Crisis (GFC). We take September 2008, the month of the bankruptcy of Lehmann Brothers and American International Group (AIG), as the starting point for this period of increased uncertainty. Home-country influences on sovereign ratings could have become more

23. Compared to yearly ratings, the usage of monthly ratings is more efficient as it makes use of all available variation in the data. Our results are virtually unchanged when using yearly averages as can be seen in Online Appendix C1. Results are also similar when we cluster only at the sovereign level. 
pronounced following the onset of the crisis. Investors became more risk-averse during the crisis; specifically, doubts about the use of sovereign bonds as quasi risk-free assets in financial models increased. Additionally, politicians and journalists intensified their critique of the agencies' decision-making and increased the public pressure not to downgrade their countries.

Note that the OLS regressions treat the dependent variable as cardinal. This implies that the difference between an "AA" and an "AA+" rating, for example, is the same as between "BB" and "BB+". In most settings, this choice has little effect on the direction and significance of variables if the number of response categories is sufficiently large (e.g., Ferrer-i-Carbonell and Frijters 2004). Nonetheless, we will also show the main results with an ordered-probit model for the discrete 21-step end-of-month rating.

\subsection{Main Results}

To reduce clutter, we do not display the results of a baseline specification that excludes our variables of interest $x_{j, i, t}$. The interested reader can find them in Online Appendix C2. The results are in line with former studies focusing on fewer agencies and shorter time periods. It is reassuring that the objective country-specific controls alone explain $86 \%$ of the variation in sovereign ratings, as indicated by the adjusted $R$-squared value.

To test whether sovereign ratings show evidence of home biases, we add one variable of interest at a time to the baseline specification. Each cell in Table 3 refers to one independent regression and shows the coefficient of the respective variable of interest. We show results for the full sample (columns (1) and (3)) and the GFC sample (columns (2) and (4)) for both OLS and ordered probit. ${ }^{24}$ As can be seen from the positive coefficient on same country in column (1), which is statistically significant at the 5\% level, agencies assign a rating to their home country that is 0.95 points higher than to other countries with the same characteristics. In other words, the rating of the home country is on average almost one rating category higher than what would be justified by how the agencies assess and weigh the economic and political fundamentals of other rated countries. The favorable treatment of the home country becomes more pronounced during the GFC period: the coefficient increases to 1.7 and becomes significant at the $1 \%$ level (column (2)). The ordered probit regression results in columns (3) and (4) confirm the significant effect of same country, at the $1 \%$ level. Taken together, this is strong evidence in favor of the home country receiving preferential treatment.

24. Online Appendix C3 shows the results for the control variables for each regression in column (1), Online Appendix C4 displays the corresponding adjusted $R$-squared values and number of observations, and Online Appendix C5 shows separate results for the pre- and post-GFC sample. The latter also investigates whether the results are affected when we add the same country dummy in order to test whether the results for the remaining variables of interests are not just capturing the same-country effect. As can be seen, this is not the case. 
TABLE 3. Home biases in sovereign ratings (all agencies pooled).

(1)

(2)

OLS
(3)

Ordered probit
(4)

Full sample GFC sample Full sample GFC sample

\begin{tabular}{lcccc}
\hline (a) Same country & $0.950^{* *}$ & $1.704^{* * *}$ & $1.591^{* * *}$ & $1.545^{* * *}$ \\
& {$[0.019]$} & {$[0.000]$} & {$[0.000]$} & {$[0.000]$} \\
(b) Export interests & 0.017 & 0.030 & 0.017 & 0.027 \\
& {$[0.358]$} & {$[0.133]$} & {$[0.144]$} & {$[0.142]$} \\
(c) Bank exposure & $0.038^{*}$ & $0.045^{*}$ & $0.076^{* * *}$ & $0.086^{* * *}$ \\
& {$[0.072]$} & {$[0.074]$} & {$[0.005]$} & {$[0.000]$} \\
(d) Geopolitical alignment (UN) & 0.005 & $0.013^{* * *}$ & 0.004 & $0.009^{* * *}$ \\
& {$[0.360]$} & {$[0.006]$} & {$[0.183]$} & {$[0.002]$} \\
(e) US military interests (aid) & 0.034 & $0.116^{* * *}$ & $0.026^{*}$ & $0.085^{* * *}$ \\
& {$[0.185]$} & {$[0.009]$} & {$[0.076]$} & {$[0.005]$} \\
(f) Common language & $0.742^{* * *}$ & $0.810^{* * *}$ & $0.452^{* * *}$ & $0.444^{* *}$ \\
& {$[0.001]$} & {$[0.003]$} & {$[0.001]$} & {$[0.022]$} \\
(g) Cultural distance (language) & $-0.021^{* * *}$ & $-0.027^{* * *}$ & $-0.017^{* * *}$ & $-0.018^{* * *}$ \\
& {$[0.000]$} & {$[0.000]$} & {$[0.000]$} & {$[0.000]$} \\
(h) Cultural distance (ethnoracial) & 0.001 & 0.003 & 0.001 & 0.002 \\
& {$[0.588]$} & {$[0.252]$} & {$[0.443]$} & {$[0.141]$} \\
\hline
\end{tabular}

Notes: The dependent variable is a country's sovereign rating on a 21-point scale. Each cell refers to a separate regression. The table displays only the coefficients on the respective variable of interest of each regression. All regressions contain the control variables as specified in Online Appendix C2, time- and agency-fixed effects. The full sample contains data from January 1990 to June 2013 (columns (1) and (3)). The GFC sample runs from September 2008 to June 2013 (columns (2) and (4)). Online Appendix C3 shows the results of the control variables for the models in column (1). Online Appendix C4 displays the adjusted $R$-squared values and the number of observation of each regression. Standard errors are clustered at both the agency-time and the sovereign level. ${ }^{*}$ Significant at $10 \% ;{ }^{* *}$ significant at $5 \% ;{ }^{* *}$ significant at $1 \%$. $p$-values are displayed in brackets.

Do rating agencies also exhibit a home bias by favoring countries that are economically, geopolitically, or culturally aligned with their home country? We use data on economic interests and geopolitical ties to test the demand channel and measures of cultural distance to test the supply channel. Starting with the measures of economic ties, our results partly support the notion that rating agencies favor countries economically aligned with their home country. Export interests does not gain statistical significance in any of the specifications in Table 3, but the second variable that proxies for economic ties, home-country bank exposure, is positive as expected and statistically significant at conventional levels in all estimations. The size of the effect is rather small but again increases after the onset of the GFC. According to column (2), an increase of the sovereign's share in the home country's bank exposure by 22 percentage points is related to a rating improvement of one point on the rating scale. This finding relates to the demand-side explanations of the home bias and supports the view that agencies and home-country banks are closely intertwined.

Although the coefficient on geopolitical alignment (UN) does not reach statistical significance at conventional levels in the full sample (columns (1) and (3)), it becomes significant at the $1 \%$ level in the GFC sample (columns (2) and (4)). The effect of US military interests (aid) on the rating behavior of the US 
agencies is positive and statistically significant in three of four specifications (columns (2)-(4)). We refrain from overinterpreting this latter finding here as it is not supported in agency-specific regressions (see Online Appendices D1-D3). Taken together, there is at best weak evidence that geopolitical ties between home and sovereign influence rating outcomes.

To test the supply-side explanations, we now turn to the role of cultural similarities between the sovereign and the home country of the rating agency. The coefficient on common language is positive as expected and statistically significant at least at the $5 \%$ level in all specifications. Countries that share a common language with the home country receive a rating that is on average 0.8 points higher, that is, almost one full rating category (column (2)). Furthermore, language can affect all home-sovereign relations, not only those in which both countries share a common language. The coefficient on cultural distance (language) is negative and significant at the $1 \%$ level in all specifications. The size of the effect is not negligible. Consider, for example, the linguistic difference between the United States and China (99), which is 20 percentage points higher than the difference between the United States and the Netherlands (79): such a distance relates to a rating that is 0.54 points lower on average in the GFC period (column (2)). This result is in line with findings of a "cultural home bias" for bank lending, investment decisions, and trade patterns (e.g, Grinblatt and Keloharju 2001; Huang 2007; Felbermayr and Toubal 2010; Giannetti and Yafeh 2012).

Cultural distance (ethnoracial) between home and sovereign, however, is not related to lower ratings. The respective coefficient is insignificant in all specifications, which thus show no evidence of discriminatory behavior of rating agencies based on race or ethnicity. The remaining explanations for the identified cultural home bias are information asymmetries and differences in risk perceptions. The next section will explore these transmission channels.

Next, we include the statistically significant proxies of economic and cultural ties from our main specification (Table 3, column (1)) in a single equation to test whether the individual effects still remain significant if jointly included in one regression. Economic and cultural ties are intertwined: countries that are culturally close to the home country are on average those with which the home country entertains close economic relations (Guiso et al. 2009). However, even after adding the two language variables in columns (1) and (2) of Table 4, respectively, the coefficients on bank exposure are comparable in size and statistically significant at conventional levels. Also, both common language and cultural distance (language) keep their signs and remain statistically significant. We conclude that the effect of economic ties is not (entirely) driven by cultural distance between the home country and the sovereign as the effect of the former remains significant when we control for the latter. Demand and supply factors both appear to play a role.

Next, we explore if both language measures are substitutes for each other. As bank exposure is not available for China, Cyprus, the respective home country and years prior to 2005, column (3) excludes this measure and focuses on the two language variables. Conditioning on each other lowers the coefficients in absolute terms, but both language variables stay statistically significant at conventional levels. Finally, column 
TABLE 4. Home biases in sovereign ratings (OLS, all agencies pooled, robustness checks).

\begin{tabular}{lcccc}
\hline & $(1)$ & $(2)$ & $(3)$ & $(4)$ \\
\hline Bank exposure & $0.030^{*}$ & $0.029^{*}$ & & \\
& {$[0.094]$} & {$[0.075]$} & & \\
Common language & $0.753^{* *}$ & & $0.473^{*}$ & $0.476^{*}$ \\
& {$[0.012]$} & & {$[0.069]$} & {$[0.068]$} \\
Cultural distance (language) & & $-0.022^{* *}$ & $-0.014^{* *}$ & $-0.015^{* *}$ \\
& & {$[0.012]$} & {$[0.018]$} & {$[0.021]$} \\
Same country & & & & -0.086 \\
& & & & {$[0.817]$} \\
Agency-fixed effects & Yes & Yes & Yes & Yes \\
Time-fixed effects & Yes & Yes & Yes & Yes \\
Adjusted $R$-squared & 0.87 & 0.87 & 0.87 & 0.87 \\
Observations & 37949 & 37949 & 75438 & 75438 \\
\hline
\end{tabular}

Notes: The dependent variable is a country's sovereign rating on a 21-point scale. Each column refers to a separate regression. The table displays only the coefficients on the respective variables of interest of each regression. All regressions contain the control variables as specified in Online Appendix C2, time- and agency-fixed effects. Data range from January 1990 to June 2013. Standard errors are clustered at both the agency-time and the sovereign level. * Significant at $10 \% ;{ }^{* *}$ significant at $5 \%$. p-values are displayed in brackets.

(4) explores the channels that could explain the positive relationship between ratings and same country. Conditioning on cultural distance, the coefficient on same country decreases in size and becomes insignificant, whereas both language variables remain statistically significant. This suggests that cultural proximity is the main transmission channel that leads to the preferential treatment of the home country. ${ }^{25}$

Our regressions so far include time- and agency-fixed effects to exploit crosscountry variation since ratings are rather sticky and they show little variation for some countries. For these countries, a potential home bias could be reflected mostly in their initial rating level and not be fully captured in an empirical setting where identification comes only from variation over time. Still, our results are robust when we run regressions according to equations (4) and (5), respectively. While column (1) of Table 5 displays the main results from Table 3 for the reader's convenience, columns (2) and (3) show the results with the additional controls. As can be seen, the findings for same country, bank exposure, and cultural distance (language) are robust to the inclusion of additional fixed effects. Same country becomes significant at the $1 \%$ level when estimating the models in equation (4) and remains so even in equation (5) where we control for all country-specific time-invariant and time-variant unobserved factors.

25. As one seminar participant suggested, cultural proximity and common language could be closely related to a sovereign's legal origin. For example, French-speaking countries are more likely to share their legal origin with France. Online Appendix C6 replicates columns (1) and (2) of Table 4 including a dummy variable that takes a value of one if the home country and rated country share the same legal origin (data from Treisman 2007). Our results are largely unaffected. The coefficients on same legal origin do not reach statistical significance with the exception of the regression with the US military interests (aid), which covers the US agencies only. 
TABLE 5. Home biases in sovereign ratings (OLS, all agencies pooled, additional fixed effects).

\begin{tabular}{|c|c|c|c|c|c|c|}
\hline & \multicolumn{2}{|c|}{$\begin{array}{c}\text { (1) } \\
\text { Equation (3) }\end{array}$} & \multicolumn{2}{|c|}{$\begin{array}{c}(2) \\
\text { Equation (4) }\end{array}$} & \multicolumn{2}{|c|}{$\begin{array}{c}\text { (3) } \\
\text { Equation (5) }\end{array}$} \\
\hline & Coefficient & Set of FE & Coefficient & Set of FE & Coefficient & Set of FE \\
\hline (a) Same country & $\begin{array}{l}0.950^{* *} \\
{[0.019]}\end{array}$ & $\begin{array}{l}\text { Agency } \\
\text { FE }\end{array}$ & $\begin{array}{l}0.681^{* * *} \\
{[0.003]}\end{array}$ & $\begin{array}{l}\text { Agency FE and } \\
\text { sovereign FE }\end{array}$ & $\begin{array}{l}0.699^{* * *} \\
{[0.001]}\end{array}$ & $\begin{array}{c}\text { Agency FE and } \\
\text { sovereign-year FE }\end{array}$ \\
\hline (b) Export interests & $\begin{array}{c}0.017 \\
{[0.358]}\end{array}$ & $\begin{array}{l}\text { Agency } \\
\text { FE }\end{array}$ & $\begin{array}{c}-0.095 \\
{[0.263]}\end{array}$ & $\begin{array}{l}\text { Agency-sovereign } \\
\text { pair FE }\end{array}$ & $\begin{array}{c}-0.216 \\
{[0.101]}\end{array}$ & $\begin{array}{l}\text { Agency-sovereign } \\
\text { pair-year FE }\end{array}$ \\
\hline (c) Bank exposure & $\begin{array}{c}0.038^{*} \\
{[0.072]}\end{array}$ & $\begin{array}{l}\text { Agency } \\
\text { FE }\end{array}$ & $\begin{array}{c}0.112^{* *} \\
{[0.022]}\end{array}$ & $\begin{array}{l}\text { Agency-sovereign } \\
\text { pair FE }\end{array}$ & $\begin{array}{c}0.023^{*} \\
{[0.100]}\end{array}$ & $\begin{array}{l}\text { Agency-sovereign } \\
\text { pair-year FE }\end{array}$ \\
\hline (d) Political alignment (UN) & $\begin{array}{c}0.005 \\
{[0.360]}\end{array}$ & $\begin{array}{l}\text { Agency } \\
\text { FE }\end{array}$ & $\begin{array}{c}-0.003 \\
{[0.848]}\end{array}$ & $\begin{array}{l}\text { Agency-sovereign } \\
\text { pair FE }\end{array}$ & $\begin{array}{c}0.006 \\
{[0.623]}\end{array}$ & $\begin{array}{l}\text { Agency-sovereign } \\
\text { pair-year FE }\end{array}$ \\
\hline (e) US military interests (aid) & $\begin{array}{c}0.034 \\
{[0.185]}\end{array}$ & $\begin{array}{l}\text { Agency } \\
\text { FE }\end{array}$ & $\begin{array}{c}0.030 \\
{[0.318]}\end{array}$ & $\begin{array}{l}\text { Agency-sovereign } \\
\text { pair FE }\end{array}$ & $\begin{array}{c}0.006 \\
{[0.573]}\end{array}$ & $\begin{array}{l}\text { Agency-sovereign } \\
\text { pair-year FE }\end{array}$ \\
\hline (f) Common language & $\begin{array}{l}0.742^{* * *} \\
{[0.001]}\end{array}$ & $\begin{array}{l}\text { Agency } \\
\text { FE }\end{array}$ & $\begin{array}{c}0.101 \\
{[0.686]}\end{array}$ & $\begin{array}{l}\text { Agency FE and } \\
\text { sovereign FE }\end{array}$ & $\begin{array}{c}0.150 \\
{[0.569]}\end{array}$ & $\begin{array}{l}\text { Agency FE and } \\
\text { sovereign-year FE }\end{array}$ \\
\hline (g) Cultural distance (language) & $\begin{array}{c}-0.021^{* * *} \\
{[0.000]}\end{array}$ & $\begin{array}{l}\text { Agency } \\
\text { FE }\end{array}$ & $\begin{array}{c}-0.008^{* *} \\
{[0.010]}\end{array}$ & $\begin{array}{l}\text { Agency FE and } \\
\text { sovereign FE }\end{array}$ & $\begin{array}{c}-0.011^{* * *} \\
{[0.001]}\end{array}$ & $\begin{array}{c}\text { Agency FE and } \\
\text { sovereign-year FE }\end{array}$ \\
\hline (h) Cultural distance (ethnoracial) & $\begin{array}{c}0.001 \\
{[0.588]}\end{array}$ & $\begin{array}{l}\text { Agency } \\
\text { FE }\end{array}$ & $\begin{array}{c}0.003 \\
{[0.199]}\end{array}$ & $\begin{array}{l}\text { Agency FE and } \\
\text { sovereign FE }\end{array}$ & $\begin{array}{c}0.002 \\
{[0.257]}\end{array}$ & $\begin{array}{c}\text { Agency FE and } \\
\text { sovereign-year FE }\end{array}$ \\
\hline
\end{tabular}

Notes: The dependent variable is a country's sovereign rating on a 21-point scale. Each cell refers to a separate regression. The table displays only the coefficients on the respective variable of interest of each regression. All regressions contain the control variables as specified in Online Appendix C2, time-fixed effects, as well as the fixed effects specified in the head row of the table. Column (1) is identical with column (1) of Table 3 to facilitate comparisons. Data range from January 1990 to June 2013. Standard errors are clustered at both the agency-time and the sovereign level. ${ }^{*}$ Significant at $10 \% ;{ }^{* *}$ significant at $5 \% ;{ }^{* * *}$ significant at $1 \%$. $p$-values are displayed in brackets.

Bank exposure reaches statistical significance at the 5\% level when introducing agencysovereign-pair-fixed effects and is still marginally significant with agency-sovereignpair-year-fixed effects ( $p$ value: 0.100). While common language loses its statistical significance, export interests, geopolitical alignment (UN), US military interests (aid), and cultural distance (ethnoracial) remain insignificant. Cultural distance (language) is negative and statistically significant at least at the 5\% level throughout Table 5. This highlights that our results are neither driven by factors that are time-invariant in our sample, such as the advantage that the United States enjoys with the US dollar being the world's reserve currency, nor by sovereign-time specific factors, such as financial market conditions in the rated country.

By pooling all agencies in one regression, we have so far implicitly assumed that each agency weighs all sovereign-specific factors in the same way as we were estimating a single coefficient per explanatory variable. We now relax this assumption and run individual regressions for each of the nine rating agencies under analysis. For each agency's home country, Figure 2 contrasts the actual rating and the predicted rating for the home country based on how each agency weighs the economic and political fundamentals of sovereigns. In other words, we compare the actual ratings (black line) with the ratings that should be assigned to the home country if it were not the home country (gray line). The figure highlights several interesting results. First, with respect to all the US agencies since the early 2000s recession, the predicted values for the United States are lower than the actual rating. While Fitch and Moody's 

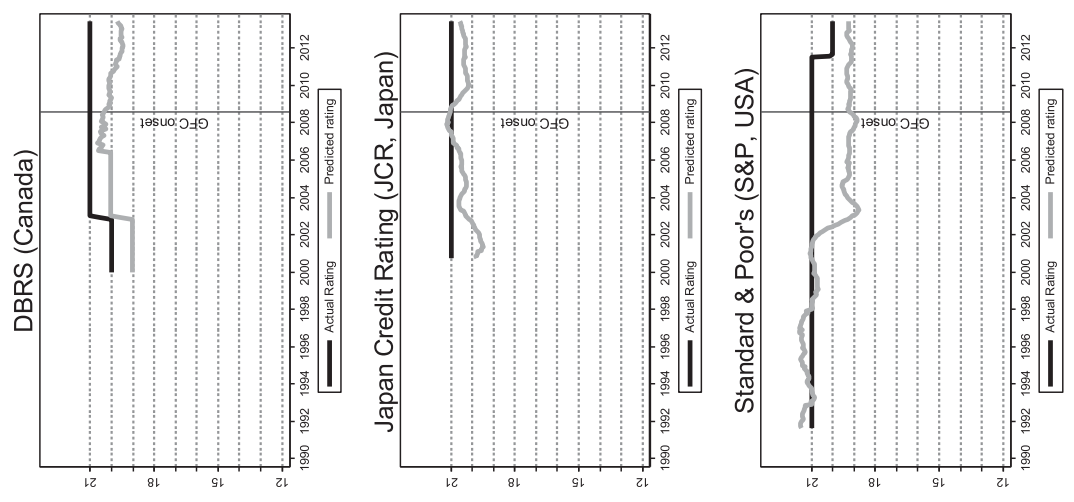

売
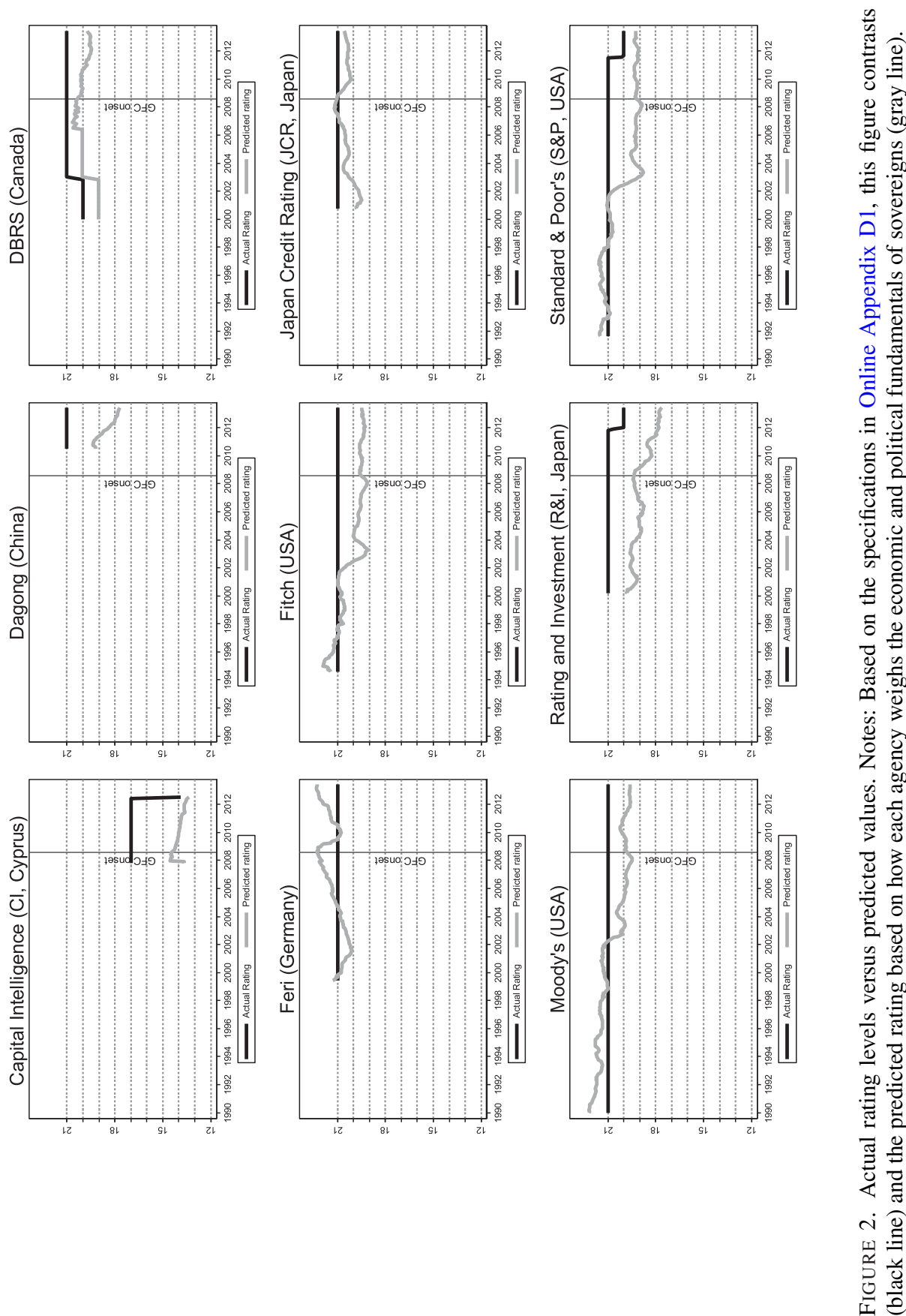
still deviate from their lower predicted value for the United States by more than one point (as of June 2013), S\&P comes closer to its predicted value after the agency downgraded its home country in August 2011. Second, although both JCR and R\&I assign a high rating to their home country Japan, the gray line indicates that only R\&I clearly applies different criteria to Japan compared to other countries. Third, Dagong's predicted rating for China is increasingly deviating from the assigned "AAA" rating as China's fundamentals have deteriorated since 2011.

However, the results for some agencies highlight a potential problem of OLS in the analysis of a bounded dependent variable. For example, Feri assigns the highest possible "AAA" (21) rating to Germany throughout the sample period. However, the predicted rating based on the treatment of the sovereign-specific factors of other sovereigns is above 21 . This implies that the coefficient on same country will be biased downward in such cases. Being aware of this caveat, it is not surprising that results from agency-specific OLS regressions show that only CI, Dagong, Fitch, and R\&I provide a significantly higher rating to the country where their headquarters is based, whereas the coefficient for S\&P is marginally significant (see Online Appendix D1). By rerunning the agency-specific regressions using ordered probit, we account for the bounded nature of the dependent variable. Online Appendix D2 shows that same country also becomes statistically significant at the $1 \%$ level for Feri, Fitch, JCR, Moody's, and S\&P, that is, those agencies for which the OLS coefficient should be negatively biased. This suggests that the home bias in sovereign ratings is a broad phenomenon and not restricted to single agencies. ${ }^{26}$

Taken together, we reject the null hypothesis of unbiased sovereign ratings. Agencies assign relatively higher ratings to their home country and to countries that are economically aligned with it in terms of bank exposure. There is also strong support for a role of cultural distance in terms of a common or similar languages, but not of ethnoracial differences. Geopolitical ties do not seem to play a decisive role.

\subsection{Exploration of Transmission Channels}

This section examines the transmission channels of the "cultural home bias" in more detail. The insignificant coefficients for cultural distance (ethnoracial) suggest that discrimination based on race and ethnicity is unrelated to rating outcomes. The two remaining explanations for the negative effect of cultural distance (language) on sovereign ratings are information asymmetries and differences in risk perception. A first test of the role of information asymmetries is to analyze the sequencing of rating changes in home countries. If home agencies have a better way to collect and process public information on the sovereign, we should observe that they initiate rating changes,

26. A closer investigation of agency-specific results again highlights the importance of cultural relatedness. For eight out of nine agencies at least one of the two language variables is statistically significant at conventional levels. Moreover, the application of an ownership definition rather than coding the home country based on the location of the agency's headquarters suggests that the ownership structure also matters. See Online Appendix D3 for a detailed discussion of the agency-specific regression results. 
TABLE 6. Exploration of transmission channels (OLS, foreign offices).

\begin{tabular}{lcccc}
\hline & $(1)$ & $(2)$ & $(3)$ & $(4)$ \\
& Feri & Fitch & Moody's & S\&P \\
\hline Cultural distance (language) & $-0.026^{*}$ & $-0.036^{* *}$ & $-0.027^{* *}$ & -0.019 \\
& {$[0.061]$} & {$[0.045]$} & {$[0.029]$} & {$[0.143]$} \\
Office in rated country & -0.643 & -0.415 & -0.593 & 1.340 \\
& {$[0.670]$} & {$[0.789]$} & {$[0.668]$} & {$[0.245]$} \\
Cultural distance (language) * office in rated country & -0.008 & 0.003 & 0.009 & -0.019 \\
& {$[0.638]$} & {$[0.878]$} & {$[0.588]$} & {$[0.202]$} \\
Adjusted $R$-squared & 0.80 & 0.90 & 0.89 & 0.90 \\
Observations & 8730 & 14814 & 16374 & 18230 \\
\hline
\end{tabular}

Notes: The dependent variable is a country's sovereign rating on a 21-point scale. Each column refers to a separate regression. The table displays only the coefficients on the respective variable of interest of each regression. All regressions contain the control variables as specified in Online Appendix C2, and time-fixed effects. Data range from January 1990 to June 2013. Standard errors are clustered at both the sovereign and the time level. * Significant at $10 \% ;{ }^{* *}$ significant at $5 \%$. p-values are displayed in brackets.

whereas foreign agencies follow these decisions with some delay (see Alsakka and ap Gwilym 2010). However, a graphical exploration shows no sign of informational advantages on part of the home agencies, which in fact seem to react more slowly to changes in economic or political circumstances than foreign agencies (see Online Appendix E1). ${ }^{27}$

Moreover, in assessing a given foreign country, smaller agencies should have a greater information disadvantage than the "Big Three", who have extensive resources, foreign offices, research staff, and contacts that make information easier to collect (see Coval and Moskowitz 1999 for a similar reasoning). Still, a reexamination of our agency-specific regressions in Online Appendices D1 and D2 suggests that information asymmetries are an unlikely cause of the cultural home bias: the coefficients on cultural distance (language) are not systematically smaller in absolute size for the "Big Three" than for the smaller agencies.

To examine more systematically whether information asymmetries are the main transmission channel, we examine whether the cultural home bias is alleviated by the existence of an office in the rated country. This relates to Giannetti and Yafeh (2012) who find that the cultural bias in bank lending is mitigated when banks have a subsidiary in the foreign country. The binary variable office takes a value of one if an agency has an office in the rated country. We restrict our analysis to the big US-based agencies, which have offices on a global scale (Fitch: 35, Moody's: 24, S\&P: 25), and Feri with its five offices. Table 6 shows that both office as well as its interaction with cultural distance (language) are not statistically significant at conventional levels for any of the four agencies. With the exception of S\&P (column (4)), the coefficient on cultural distance (language) remains negative and statistically significant in all specifications.

27. This is in line with evidence in Li et al. (2006) for ratings of Japanese corporations. 
TABLE 7. Exploration of transmission channels (OLS, transparency, trust and government stability).

\begin{tabular}{|c|c|c|c|c|c|c|c|}
\hline & $\begin{array}{l}\text { (1) } \\
\text { All }\end{array}$ & $\begin{array}{l}\text { (2) } \\
\text { All }\end{array}$ & $\begin{array}{l}(3) \\
\text { Feri }\end{array}$ & $\begin{array}{l}(4) \\
\text { Feri }\end{array}$ & $\begin{array}{l}(5) \\
\text { Feri }\end{array}$ & $\begin{array}{l}(6) \\
\text { Feri }\end{array}$ & $\begin{array}{l}(7) \\
\text { Feri }\end{array}$ \\
\hline Cultural distance (language) & $\begin{array}{c}-0.021^{* * *} \\
{[0.000]}\end{array}$ & $\begin{array}{c}-0.020^{* * *} \\
{[0.000]}\end{array}$ & $\begin{array}{c}-0.020^{* *} \\
{[0.025]}\end{array}$ & $\begin{array}{c}-0.019^{* *} \\
{[0.035]}\end{array}$ & $\begin{array}{r}-0.015 \\
{[0.384]}\end{array}$ & & \\
\hline Informational transparency & & $\begin{array}{c}0.032^{*} \\
{[0.054]}\end{array}$ & & $\begin{array}{c}0.026 \\
{[0.443]}\end{array}$ & & & \\
\hline Bilateral trust & & & & & $\begin{array}{c}3.741^{*} \\
{[0.099]}\end{array}$ & $\begin{array}{l}5.320^{* * *} \\
{[0.000]}\end{array}$ & $\begin{array}{l}5.471^{* * *} \\
{[0.000]}\end{array}$ \\
\hline Government stability & & & & & & & $\begin{array}{l}0.369^{* * *} \\
{[0.004]}\end{array}$ \\
\hline Adjusted $R$-squared & 0.87 & 0.87 & 0.80 & 0.80 & 0.85 & 0.84 & 0.85 \\
\hline Observations & 75438 & 73626 & 8730 & 8511 & 2334 & 2334 & 2334 \\
\hline
\end{tabular}

Notes: The dependent variable is a country's sovereign rating on a 21-point scale. Each column refers to a separate regression. The regression contains the control variables as specified in Online Appendix C2 and timeand agency-fixed effects. Data in columns (1) and (2) range from January 1990 to June 2013. Data in columns (3)-(7) range from June 1999 to June 2013. Standard errors are clustered at both the sovereign and the time level. ${ }^{*}$ Significant at $10 \% ;{ }^{* *}$ significant at $5 \%$; ${ }^{* *}$ significant at $1 \%$. p-values are displayed in brackets.

The finding that the local presence of agency staff does not mitigate the cultural home bias suggests that information asymmetries are not the main transmission channel. ${ }^{28}$

As a last test for the role of information asymmetries, we use a sovereign-specific measure of informational transparency from Williams (2015). If information was the main channel via which linguistic distance is affecting sovereign rating decisions, the coefficient on cultural distance (language) should become smaller in absolute terms once we control for informational transparency in rated countries. As can be seen in column (2) of Table 7, the effect of cultural distance (language) remains virtually unaffected. This further increases our confidence to discard explanations based on information asymmetries.

The remaining explanation of the cultural home bias is that cultural distance (language) leads to a more pessimistic perception of the risks associated with a sovereign. Therefore, we want to explore in more detail why linguistic distance can affect risk perceptions. Our explanation relates to Guiso et al. (2009), who show in one of their specifications that linguistic distance is a determinant of bilateral trust. Higher bilateral trust should be related to a more optimistic perception of the same risks-in particular in response to the soft information provided by the sovereign. If the effect of cultural proximity works primarily via higher levels of bilateral trust, the coefficient on cultural distance (language) should become insignificant once this is controlled for.

Data on bilateral trust are available for a limited set of European countries (see, e.g., Guiso et al. 2009), which is why we focus on the German agency Feri to test this

28. A critical reader might argue that the selection of the locations of foreign offices could be endogenous, that is, agencies might place offices in countries where they need more information gathering. However, the correlation between the existence on a foreign office and informational transparency in a rated country (data from Williams 2015) is consistently positive and ranges between 0.075 (Feri) and 0.258 (S\&P). It thus seems that more offices are located in countries with comparatively good information transparency, which works in our favor. 
channel (column (3)). Specifically, we use the trust level of a representative German citizen toward a randomly selected individual of the rated country. Following Guiso et al. (2009), the time-invariant trust level is constructed by coding the answers to the following Eurobarometer question on a 4-point scale: "I would like to ask you a question about how much trust you have in people from various countries. For each, please tell me whether you have a lot of trust, some trust, not very much trust, or no trust at all." 29 As can be seen from column (4), the coefficient on cultural distance (language) is again unaffected by the inclusion of informational transparency when focusing on Feri (column (3)), once again providing evidence against information asymmetries as a channel. As expected, the coefficient on cultural distance (language) becomes smaller and statistically insignificant when we add bilateral trust instead (column (5)). The coefficient on bilateral trust in turn is positive and statistically significant. As differences in private information are not fully observable by nature, we cannot completely rule out all explanations based on information asymmetries. The presented evidence, however, strongly suggests that rating decisions are affected by cultural proximity due to higher bilateral trust, creating a more optimistic perception of the risks associated with political and economic fundamentals.

This interpretation is further exemplified by distinguishing between the perceived and the "objective" credibility of a sovereign's government. Assume, as postulated, that bilateral trust affects the home country-specific perception of a specific sovereign's credibility. Bilateral trust should then remain significant when adding an "objective" sovereign-specific proxy for credibility that is identical for all home countries. To test this, we include the variable "Government Stability" from the International Country Risk Guide (ICRG) as a proxy for government credibility. ${ }^{30}$ As can be seen from a comparison of columns (6) and (7), the coefficient on bilateral trust becomes slightly larger and remains significant at the $1 \%$ level. We take this as further support that the cultural home bias is indeed driven by bilateral trust, which leads to a more optimistic perception of risks.

\subsection{Further Robustness Checks}

In this final section, we test the robustness of our results with respect to further alterations in the empirical strategy. First, we control for selection of countries into the sample of rated countries (see also Beaulieu et al. 2012). For example, a sovereign could be more likely to request a rating from an agency from which it expects a more favorable rating. To control for a possible selection bias, we rerun our model from Table 3 (column (1)) as a Heckman selection model. We start by estimating a

29. The data show that Germans trust Germans the most. We are grateful to Shu Yu for sharing the trust data with us. See Yu et al. (2015) for details.

30. According to the ICRG methodology, "Government Stability" is "an assessment both of the government's ability to carry out its declared program(s), and its ability to stay in office." It is based on three subcomponents: Government Unity, Legislative Strength, and Popular Support. A government's credibility should depend on these three factors that are linked to its stability. 
Heckman model without exclusion variables. We then use the number of sovereigns that are rated by the respective agency in the previous period, the number of the big three agencies that rate a sovereign in the previous period, or both as exclusion variables. Arguably, a sovereign is more likely to be rated by an agency if that agency covers a larger set of countries and if the market-dominating agencies rate a particular country. At the same time, it is difficult to come up with an explanation as to why these two measures of country coverage should directly affect rating levels. The results support our earlier conclusions (see Online Appendix F1 for full regression results).

Second, we run quantile regressions for the three robustly significant variables of interest that exhibit enough variation to learn whether the biases vary across the rating distribution. Certain rating thresholds are of particular importance for investment decisions (e.g., Jaramillo and Tejada 2011). The literature on market segmentation, for example, highlights the importance of the threshold separating investment from noninvestment grade categories (e.g., Rigobon 2002). In addition to the quintiles, we include the investment-grade threshold ("BB+"/"BBB-"), the eligibility threshold for the US pension fund investments ("A-"/“A"), and the eligibility threshold for money market fund purchases ("AA"/"AA+"). Quantile regressions also serve as a test for outliers by showing the size and direction of the relationships along the rating distribution. The results in Table 8 confirm the robustness of the language variables, which are both statistically significant at the $1 \%$ level at all selected points of the rating distribution, including all three important thresholds. Bank exposure seems to matter mostly at lower quantiles, including the investment-grade threshold, and ceases to be relevant for sovereigns with higher ratings. The coefficients on common language and cultural distance (language) also become more accentuated at the lower end of the rating distribution in the full sample. Taken together, this underlines the importance of the biases as they affect sovereign rating decisions at critical thresholds.

Third, we allow for a differential assessment of the economic and political fundamentals of the home country compared to foreign countries. For this purpose, we interact the same-country dummy with each of the economic and political fundamentals. With the exception of inflation, home agencies put more weight on economic factors in foreign countries (see Online Appendix F2 for details). Government debt and current account deficits are viewed more negatively in foreign countries than at home. With regard to political factors, agencies put weight on different factors at home than abroad. Although agencies pay attention to their home countries' internal conflicts, it is only when dealing with foreign countries that they take into account external conflicts and risks associated with elections. This confirms that the same risks are perceived differently at home and abroad.

Finally, inspired by the literature on corporate ratings, we analyze the potential role that the business model of rating agencies plays, specifically conflicts of interest that could arise from an "issuer-pays" model. Afonso (2003, p. 60) mentions the possibility that agencies may attempt "to gain market share by giving some countries a notch more than the competitors". Similarly, White (2010, p. 215) suggests that a "rating agency might shade its rating upward so as to keep the issuer happy and forestall the issuer's taking its rating business to a different rating agency". Empirical evidence on corporate 


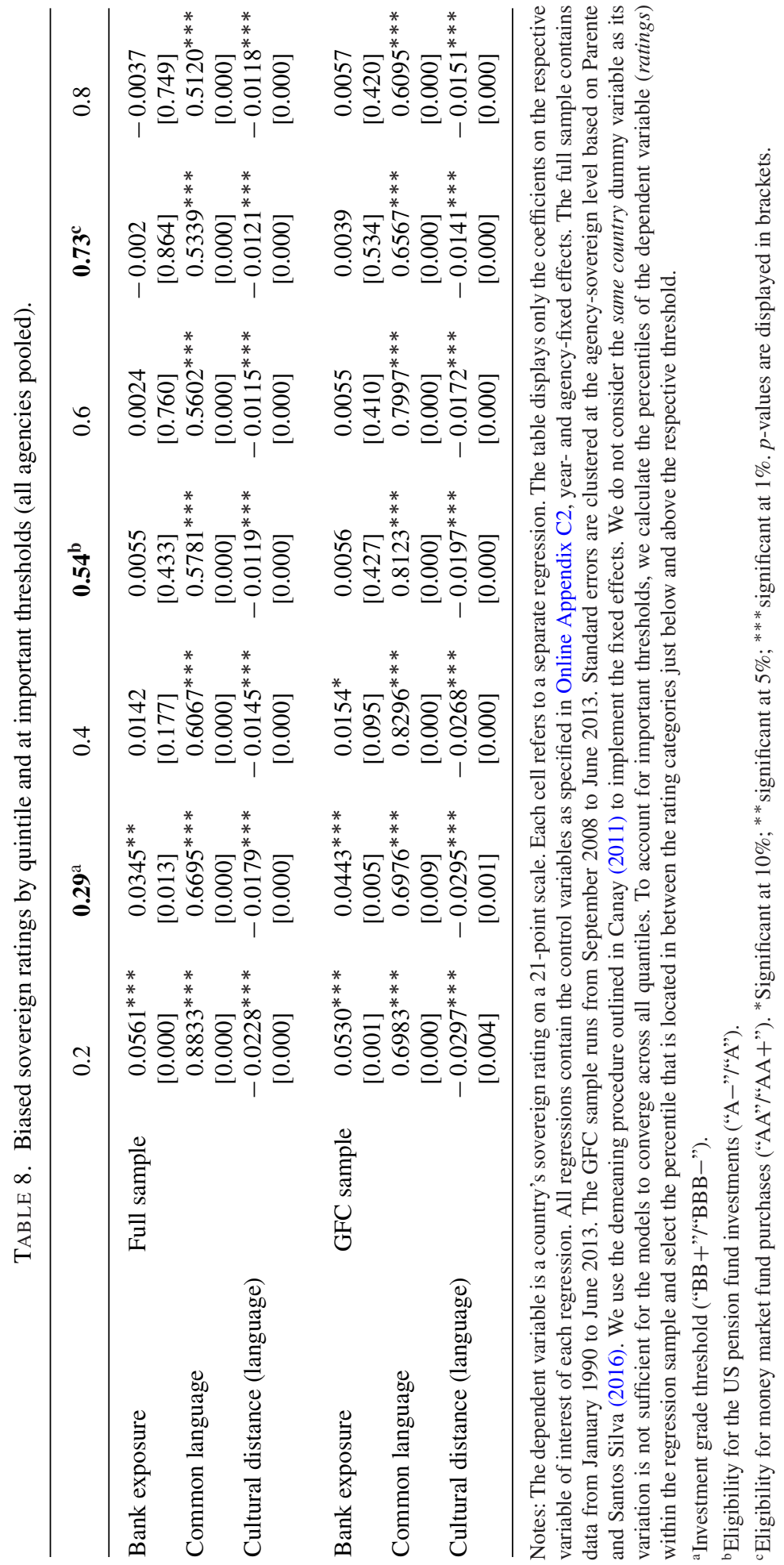


ratings shows that solicited ratings are systematically higher than unsolicited ones (e.g., Poon 2003). One might thus expect an "optimistic bias" when countries pay for their ratings themselves (see also Bruno et al. 2016). We analyze DBRS, Moody's, R\&I, and $\mathrm{S} \& \mathrm{P}$, the four agencies that provide a significant number of both solicited and unsolicited ratings (Online Appendix A3). Neither the results from a regression model that adds a binary variable for an unsolicited rating, nor those from a regression model that further adds its interaction with our variables of interest indicates that solicitation status is relevant for sovereign rating decisions (Online Appendix F3). Moreover, our main results remain virtually unaffected across specifications. ${ }^{31}$

\section{Conclusions}

Using data on 143 sovereigns issued by nine agencies based in six countries, this article shows that sovereign ratings exhibit significant biases. The average agency assigns a rating to its home country that is almost one rating category higher than what seems justified by how it assesses other sovereigns. Most importantly, we find that countries that are culturally closer receive a better treatment: the larger the linguistic differences between home and sovereign, that is, the more unfamiliar a language, the lower the assigned rating on average. There is also evidence that agencies on average assign relatively higher ratings to countries to which their home country's banks have a larger risk exposure. Cultural proximity seems to be the main transmission channel that causes the home country to be treated differently. These results are robust to the choice of estimation methods, the inclusion of country-pair- or rated-country-fixed effects, and selection into the sample of rated countries. Moreover, the home biases are neither only restricted to the US agencies nor to the smaller agencies.

Regarding the transmission channels, we hypothesized that the bias toward culturally closer countries could arise from more and better information or a more optimistic perception of the risks associated with political and economic fundamentals. If the differences were solely due to differential access to information, controlling for informational transparency, or the existence of a foreign office in a rated country should alleviate the bias. However, we find no support for explanations based on information asymmetries. Although we cannot entirely rule out that the biases are to some degree driven by differential access to information, the most plausible explanation is that cultural proximity relates to a more optimistic perception of risks. Specifically, we provide evidence suggesting that greater trust between culturally closer countries leads to the home bias in sovereign ratings. It thus appears to be the case that ratings suffering from a home bias are not "truly better", that is, more precise, but rather "inflated." This

31. Our results are also qualitatively unaffected when we account for "rating shopping" in the sense that a sovereign requests a rating from its home or culturally closer agencies in case its unsolicited rating from the "Big Three" was downgraded (see Online Appendix F4). Moreover, Online Appendix F5 shows that of all smaller agencies only DRBS is slightly more likely to start providing a rating to countries that have recently been downgraded. Still, those ratings are not clearly better than those of the "Big Three." 
is of concern as investors are often forced by regulation to adjust their portfolio in response to rating changes and empirical evidence suggests that they do not correct for biased ratings (Strobl and Xia 2012). Biases of one rating category can thus make a big difference to a country's degree of access to international capital markets and its refinancing costs.

These results should not be taken as evidence that rating agencies do not fulfill an economically relevant and potentially efficiency-enhancing role. Since their judgments are based on incomplete and partly unverifiable information, it may be rational to rely on heuristics such as bilateral trust. Still, given the importance of sovereign ratings, the following policy implications can be derived from our results. First, regulators could increase transparency of rating decisions. Although the value added of ratings relies partly on discretionary decisions and subjective assessments, publicly disclosing when and why rating committees deviate from initial rating proposals would provide important information to investors. Second, regulation should aim at fostering competition to decrease reliance on a few big agencies. Based on our results, a promising approach would be to embrace the plurality of methods and opinions. In cases where economic arguments support the use of external ratings, regulation should require ratings by more than one agency, ideally from different countries and cultural backgrounds. This would provide a more comprehensive risk assessment and should mitigate the effects of home biases in sovereign ratings.

\section{References}

Abbas, S. M. Ali, Nazim Belhocine, Asmaa A. ElGanainy, and Mark A. Horton (2010). "A Historical Public Debt Database." IMF Working Paper No. 10/245. International Monetary Fund, Washington, DC. Available at http://www.imf.org/external/pubs/cat/longres.cfm?sk=24332.0 (accessed 29 April 2013).

Afonso, António (2003). "Understanding the Determinants of Sovereign Debt Ratings: Evidence for the Two Leading Agencies." Journal of Economics and Finance, 27, 56-74.

Afonso, António, Davide Furceri, and Pedro Gomes (2012). "Sovereign Credit Ratings and Financial Markets Linkages: Application to European Data." Journal of International Money and Finance, 31, 606-638.

Alesina, Alberto, Arnaud Devleeschauwer, William Easterly, Sergio Kurlat, and Romain Wacziarg (2003). "Fractionalization." Journal of Economic Growth, 8, 155-194.

Alsakka, Rasha and Owain ap Gwilym (2010). "Leads and Lags in Sovereign Credit Ratings." Journal of Banking \& Finance, 34, 2614-2626.

Alsakka, Rasha and Owain ap Gwilym (2012). "The Causes and Extent of Split Sovereign Credit Ratings in Emerging Markets." Emerging Markets Finance \& Trade, 48, 4-24.

Ammer, John and Frank Packer (2000). "How Consistent Are Credit Ratings? A Geographic and Sectoral Analysis of Default Risk.” International Finance Discussion Papers No. 668. Board of Governors of the Federal Reserve System, Washington, DC.

Angrist, Joshua D. and Jörn-Steffen Pischke (2008). Mostly Harmless Econometrics: An Empiricist's Companion. Princeton University Press.

Archer, Candace C., Glen Biglaiser, and Karl DeRouen, Jr (2007). "Sovereign Bonds and the 'Democratic Advantage': Does Regime Type Affect Credit Ratings in the Developing World?" International Organization, 61, 341-365.

Bar-Isaac, Heski and Joel Shapiro (2011). "Credit Ratings Accuracy and Analyst Incentives." American Economic Review: Papers \& Proceedings, 101, 120-130. 
Barro, Robert J. and Jong-Wha Lee (2005). "IMF Programs: Who Is Chosen and What Are the Effects?" Journal of Monetary Economics, 52, 1245-1269.

Bartels, Bernhard (2014). "Why Rating Agencies Disagree on Sovereign Ratings." Gutenberg School of Management and Economics \& Research Unit "Interdisciplinary Public Policy" Discussion Paper No. 1416. University of Mainz, Mainz, Germany.

Beaulieu, Emily, Gary W. Cox, and Sebastian Saiegh (2012). "Sovereign Debt and Regime Type: Reconsidering the Democratic Advantage." International Organization, 66, 709-738.

Beck, Thorsten, George Clarke, Alberto Groff, Philip Keefer, and Patrick Walsh (2001). "New Tools in Comparative Political Economy: The Database of Political Institutions." World Bank Economic Review, 15, 165-176.

Becker, Gary S. (1961). The Economics of Discrimination, 2nd ed. University of Chicago Press.

Biglaiser, Glen and Joseph L. Staats (2012). "Finding the 'Democratic Advantage' in Sovereign Bond Ratings: The Importance of Strong Courts, Property Rights Protection, and the Rule of Law." International Organization, 66, 515-535.

Block, Steven A. and Paul M. Vaaler (2004). "The Price of Democracy: Sovereign Risk Ratings, Bond Spreads and Political Business Cycles in Developing Countries." Journal of International Money and Finance, 23, 917-946.

Böninghausen, Benjamin and Michael Zabel (2015). "Credit Ratings and Cross-border Bond Market Spillovers." Journal of International Money and Finance, 53, 115-136.

Borensztein, Eduardo and Ugo Panizza (2009). "The Costs of Sovereign Default." IMF Staff Papers, $56,683-741$.

Borensztein, Eduardo, Kevin Cowan, and Patricio Valenzuela (2013). "Sovereign Ceilings 'Lite'? The Impact of Sovereign Ratings on Corporate Ratings." Journal of Banking \& Finance, 37, 4014-4024.

Brennan, Michael J. and H. Henry Cao (1997). "International Portfolio Investment Flows." Journal of Finance, 52, 1851-1880.

Bruno, Valentina, Jess Cornaggia, and Kimberly J. Cornaggia (2016). "Does Regulatory Certification Affect the Information Content of Credit Ratings?" Management Science, 62, 1578-1597.

Canay, Ivan A. (2011). "A Simple Approach to Quantile Regression for Panel Data." Econometrics Journal, 14, 368-386.

Cantor, Richard Martin and Frank Packer (1996). "Determinants and Impact of Sovereign Credit Ratings." Economic Policy Review, 2, 37-53.

Chan, Kalok, Vicentiu Covrig, and Lilian Ng (2005). "What Determines the Domestic Bias and Foreign Bias? Evidence from Mutual Fund Equity Allocations Worldwide." Journal of Finance, $60,1495-1534$.

Cole, Harold L. and Patrick J. Kehoe (1998). "Models of Sovereign Debt: Partial versus General Reputations." International Economic Review, 539, 55-70.

Cornaggia, Jess, Kimberly J. Cornaggia, and Han Xia (2016). "Revolving Doors on Wall Street." Journal of Financial Economics, 120, 400-419.

Cornaggia, Jess, Kimberly J. Cornaggia, and Ryan D. Israelsen (2015). "Credit Ratings and the Cost of Municipal Financing." Draft. Available at http://ssrn.com/abstract=2304373 (accessed 3 February 2016).

Coval, Joshua D. and Tobias J. Moskowitz (1999). "Home Bias at Home: Local Equity Preference in Domestic Portfolios.” Journal of Finance, 54, 2045-2073.

De Haan, Jakob and Fabian Amtenbrink (2011). "Credit Rating Agencies.” DNB Working Paper No. 278. De Nederlandsche Bank, Amsterdam, Netherlands.

DiGiuseppe, Matthew R., Colin M. Barry, and Richard W. Frank (2012). "Good for the Money: International Finance, State Capacity, and Internal Armed Conflict." Journal of Peace Research, 49, 391-405.

Dreher, Axel and Martin Gassebner (2008). "Does Political Proximity to the U.S. Cause Terror?" Economics Letters, 99, 27-29.

Durbin, Erik and David Ng (2005). "The Sovereign Ceiling and Emerging Market Corporate Bond Spreads." Journal of International Money and Finance, 24, 631-649. 
Eaton, Jonathan and Mark Gersovitz (1981). "Debt with Potential Repudiation: Theoretical and Empirical Analysis.” Review of Economic Studies, 48, 289-309.

Felbermayr, Gabriel J. and Farid Toubal (2010). "Cultural Proximity and Trade." European Economic Review, 54, 279-293.

Ferrer-i-Carbonell, Ada and Paul Frijters (2004). "How Important is Methodology for the Estimates of the Determinants of Happiness?" Economic Journal, 114, 641-659.

Ferri, Giovanni, Li-gang Liu, and Joseph E. Stiglitz (1999). "The Procyclical Role of Rating Agencies: Evidence from the East Asian Crisis." Economic Notes, 28, 335-355.

Flandreau, Marc (2006). "Home Biases, Nineteenth Century Style." Journal of the European Economic Association, 4, 634-643.

French, Kenneth R. and James M. Poterba (1991). "Investor Diversification and International Equity Markets." American Economic Review, 81, 222-226.

Gaillard, Norbert (2012). A Century of Sovereign Ratings. Springer.

Gärtner, Manfred, Björn Griesbach, and Florian Jung (2011). "PIGS or Lambs? The European Sovereign Debt Crisis and the Role of Rating Agencies." International Advances in Economic Research, 17, 288-299.

Gehrig, Thomas (1993). "An Information Based Explanation of the Domestic Bias in International Equity Investment.” Scandinavian Journal of Economics, 95, 97-109.

Gennaioli, Nicola, Alberto Martin, and Stefano Rossi (2014). "Sovereign Default, Domestic Banks, and Financial Institutions." Journal of Finance, 69(2, 819-866.

Giannetti, Mariassunta and Yishay Yafeh (2012). "Do Cultural Differences Between Contracting Parties Matter? Evidence from Syndicated Bank Loans." Management Science, 58, 365-383.

Grinblatt, Mark and Matti Keloharju (2001). "How Distance, Language, and Culture Influence Stockholdings and Trades." Journal of Finance, 56, 1053-1073.

Grossman, Herschel I., John B., and Van Huyck (1988). "Sovereign Debt as a Contingent Claim: Excusable Default, Repudiation, and Reputation." American Economic Review, 78, 1088-1097.

Guiso, Luigi, Paola Sapienza, and Luigi Zingales (2006). "Does Culture Affect Economic Outcomes?" Journal of Economic Perspectives, 20, 23-48.

Guiso, Luigi, Paola Sapienza, and Luigi Zingales (2009). "Cultural Biases in Economic Exchange?" Quarterly Journal of Economics, 124, 1095-1131.

Güttler, André and Mark Wahrenburg (2007). "The Adjustment of Credit Ratings in Advance of Defaults." Journal of Banking \& Finance, 31, 751-767.

Haque, Nadeem U., Nelson Mark, and Donald J. Mathieson (1998). "The Relative Importance of Political and Economic Variables in Creditworthiness Ratings." IMF Working Paper WP/98/46. International Monetary Fund, Washington, DC.

Hill, Paula, Robert Brooks, and Robert Faff (2010). "Variations in Sovereign Credit Quality Assessments Across Rating Agencies." Journal of Banking \& Finance, 34, 1327-1343.

Huang, Rocco R. (2007). "Distance and Trade: Disentangling Unfamiliarity Effects and Transport Cost Effects." European Economic Review, 51, 161-181.

Huberman, Gur (2001). "Familiarity Breeds Investment." Review of Financial Studies, 14, 659-680.

Jaramillo, Laura and Catalina Michelle Tejada (2011). "Sovereign Credit Ratings and Spreads in Emerging Markets: Does Investment Grade Matter?” IMF Working Paper WP/11/44. International Monetary Fund, Washington, DC.

Kaminsky, Graciela and Sergio L. Schmukler (2002). "Emerging Market Instability: Do Sovereign Ratings Affect Country Risk and Stock Returns?" World Bank Economic Review, 16, 171-195.

Kang, Jun-Koo and René M. Stulz (1997). "Why Is There a Home Bias? An Analysis of Foreign Portfolio Equity Ownership in Japan." Journal of Financial Economics, 46, 3-28.

Kilka, Michael and Martin Weber (2000). "Home Bias in International Stock Return Expectations." Journal of Psychology and Financial Markets, 1, 176-192.

Kolo, Philipp (2012). "Measuring a New Aspect of Ethnicity-The Appropriate Diversity Index." Ibero America Institute for Economic Research (IAI) Discussion Papers No. 221. University of Goettingen, Goettingen, Germany.

Laeven, Luc and Fabián Valencia (2012). "Systemic Banking Crises Database: An Update." IMF Working Paper No. 12/163. International Monetary Fund, Washington, DC. 
Larraín, Guillermo, Helmut Reisen, and Julia Von Maltzan (1997). "Emerging Market Risk and Sovereign Credit Ratings.” OECD Development Centre Working Paper No. 124. Organisation for Economic Co-operation and Development, Paris, France.

Lewis, M. Paul (2009). Ethnologue: Languages of the World, 16th ed. Summer Institute of Linguistics (SIL).

Li, Joanne, Yoon S. Shin, and William T. Moore (2006). "Reactions of Japanese Markets to Changes in Credit Ratings by Global and Local Agencies." Journal of Banking \& Finance, 30, 1007-1021.

Marshall, Monty G., Ted Robert Gurr, and Keith Jaggers (2013). Polity IV Project: Political Regime Characteristics and Transitions, 1800-2012. Center for Systemic Peace, Vienna, VA.

Mayer, Thierry and Soledad Zignago (2011). "Notes on CEPII's Distances Measures (GeoDist)." CEPII Working Paper No. 2011-25. Centre d'Etudes Prospectives et d'Informations Internationales, Paris, France.

McCallum, John T. (1995). "National Borders Matter: Canada-U.S. Regional Trade Patterns." American Economic Review, 85, 615-623.

Melitz, Jacques (2008). "Language and Foreign Trade.” European Economic Review, 52, 667-699.

Panizza, Ugo, Federico Sturzenegger, and Jeromin Zettelmeyer (2009). "The Economics and Law of Sovereign Debt and Default." Journal of Economic Literature, 47, 651-698.

Parente, Paulo M.D.C. and João M.C. Santos Silva (2016). "Quantile Regression with Clustered Data." Journal of Econometric Methods, 5, 1-15.

Poon, Winnie P.H. (2003). “Are Unsolicited Credit Ratings Biased Downward?” Journal of Banking \& Finance, 27, 593-614.

Presbitero, Andrea F., Gregory F. Udell, and Alberto Zazzaro (2014). "The Home Bias and the Credit Crunch: A Regional Perspective.” Journal of Money, Credit and Banking, 46, 53-85.

Qian, Nancy and David Yanagizawa (2009). "The Strategic Determinants of US Human Rights Reporting: Evidence from the Cold War." Journal of the European Economic Association, 7, 446-457.

Ravina, Enrichetta (2008). "Love \& Loans: The Effect of Beauty and Personal Characteristics in Credit Markets.” American Law \& Economics Association Annual Meetings Paper No. 67. The Berkeley Electronic Press, Berkeley, CA.

Rigobon, Roberto (2002). "The Curse of Non-Investment Grade Countries.” Journal of Development Economics, 69, 423-449.

Rose, Andrew K. (2005). "One Reason Countries Pay Their Debts: Renegotiation and International Trade." Journal of Development Economics, 77, 189-206.

S\&P (2012). How We Rate Sovereigns. Standard \& Poor's Global Credit Portal: Ratings Direct. Standard \& Poor's, New York, NY.

Sarkissian, Sergei and Michael J. Schill (2004). "The Overseas Listing Decision: New Evidence of Proximity Preference.” Review of Financial Studies, 17, 769-809.

Shin, Yoon S. and William T. Moore (2003). "Explaining Credit Rating Differences between Japanese and U.S. Agencies." Review of Financial Economics, 12, 327-344.

Spolaore, Enrico and Romain Wacziarg (2009). "The Diffusion of Development." Quarterly Journal of Economics, 124, 469-529.

Stiglitz, Joseph E. (1973). "Approaches to the Economics of Discrimination." American Economic Review, 63, 287-295.

Strezhnev, Anton and Erik Voeten (2012). United Nations General Assembly Voting Data. Available at http://hdl.handle.net/1902.1/12379 (accessed 25 October 2012).

Strobl, Günter and Han Xia (2012). "The Issuer-Pays Rating Model and Ratings Inflation: Evidence from Corporate Credit Ratings." Working paper. Available at http://ssrn.com/abstract $=2002186$ (accessed 5 November 2015).

Strong, Norman and Xinzhong Xu (2003). "Understanding the Equity Home Bias: Evidence from Survey Data." Review of Economics and Statistics, 85, 307-312.

Tesar, Linda L. and Ingrid M. Werner (1995). "Home Bias and High Turnover." Journal of International Money and Finance, 14, 467-492.

Tomz, Michael and Mark L. J. Wright (2007). "Do Countries Default in 'Bad Times'?” Journal of the European Economic Association, 5, 352-360. 
Treisman, Daniel (2007). "What Have We Learned About the Causes of Corruption From Ten Years of Cross-National Empirical Research?" Annual Review of Political Science, 10, 211-244.

Vaaler, Paul M., Burkhard N. Schrage, and Steven A. Block (2006). "Elections, Opportunism, Partisanship and Sovereign Ratings in Developing Countries." Review of Development Economics, $10,154-170$.

White, Lawrence J. (2010). "Markets: The Credit Rating Agencies." Journal of Economic Perspectives, 24, 211-226.

Williams, Andrew (2015). “A Global Index of Information Transparency and Accountability.” Journal of Comparative Economics, 43, 804-824.

Wolf, Holger (2000). "International Home Bias in Trade." Review of Economics and Statistics, 82, $555-563$.

Yeyati, Eduardo Levy and Ugo Panizza (2011). "The Elusive Costs of Sovereign Defaults." Journal of Development Economics, 94, 95-105.

Yu, Shu, Jakob de Haan, and Sjoerd Beugelsdijk (2015). "Trade, Trust and the Rule of Law." European Journal of Political Economy, 37, 102-115.

\section{Supplementary Data}

Supplementary data are available at JEEA online. 